\title{
Revision of the genus Heterobrissus (Echinoidea), with a new species from Sardinia, and redefinition of Heterobrissus niasicus (Doderlein, I90I) in Echinopneustes n. gen.
}

\author{
Enrico Borghi' \& Paolo Stara ${ }^{2}$ \\ ${ }^{1}$ Società Reggiana di Scienze Naturali, Via Tosti 1, 42124 Reggio Emilia, Italy; e-mail: enrico.borghi20@gmail.com \\ ${ }^{2}$ Centro Studi di Storia Naturale del Mediterraneo, c/o Museo di Storia Naturale Aquilegia, Via S. Francesco, Masullas, Ori- \\ stano, Italy; e-mail: paolostara@yahoo.it
}

ABSTRACT

\begin{abstract}
Morphological characters previously unknown in Heterobrissus montesi Manzoni et Mazzetti, 1878, the type-species of the genus Heterobrissus Manzoni et Mazzetti, 1878, such as the oral plate structure and the position of the periproct, are herein described based on topo-typic material from the Middle Miocene of the Northern Apennines (Italy). Similar, well preserved specimens from the Early Miocene of Sardinia are attributed to Heterobrissus lubellii n. sp., which differs from $H$. montesi by its longer and wider petals and the peristome farther from the anterior margin of the test. The new available data confirm also that the genus Archaeopneustes Gregory, 1892 is junior synonym with Heterobrissus. Unreported specimens from the Late Oligocene of Alicante (Spain) enable to illustrate the plastron structure and other so far unknown features in Pygospatangus salvae Cotteau, 1890, the type species of the genus Pygospatangus Cotteau, 1890, and indicates that Pygospatangus is a junior synonym with Heterobrissus. Heterobrissus salvae differs from $H$. montesi mainly by its thicker shell and longer plates in the proximal part of the oral ambulacra I and V. The Recent species Heterobrissus niasicus (Döderlein, 1901), H. erinaceus Baker et Rowe, 1990 and H. gigas Baker et Rowe, 1990, from the Indo-Pacific, are herein transferred to Echinopneustes n. gen. Echinopneustes differs from Heterobrissus mainly by the labrum extending only to the adjoining ambulacral plate 2, not to plate 3 as in Heterobrissus, by the periproct being marginal, not inframarginal as in Heterobrissus, and bounded by the fifth plates in the interambulacrum 5, not by the fourth. The distribution of Heterobrissus, so far known from the Burdigalian of Sardinia, the Langhian of Northern Italy and the Serravallian of Cyprus, is extended to the Late Oligocene of Spain and to the Recent, with H. hystrix (Agassiz, 1880), today living in the Carribbean area. The functional morphology of the test, supported by actualistic comparison and by data taken from sedimentary settings and the associated taxa, indicates that Heterobrissus was an epibenthic feeder, preferring muddy outer shelf environments with tropical climate.
\end{abstract}

\section{INTRODUCTION}

Heterobrissus montesi Manzoni et Mazzetti, 1878, the type-species of the genus Heterobrissus
Manzoni \& Mazzetti, 1878, was described on the basis of a single poorly preserved specimen from the Langhian Pantano Formation of Montese, near Modena (Northern Italy). This species was subse- 
quently recorded in the same Formation from a number of other localities in the Northern Apennines (Manzoni, 1879, 1880; Mazzetti, 1881; Stefanini, 1908), and from the Early Burdigalian Nurallao formation of Isili, Sardinia (Stara et al., 2012). Heterobrissus formai Airaghi, 1901 and $H$. cypriotes Currie, 1935 were instituted on the basis of fossil material from the Langhian of Piedmont (Northern Italy) and the Serravallian of Cyprus, respectively. Heterobrissus cypriotes was subsequently considered as a junior synonym with the type-species by Smith \& Gale (2009). Four Recent species are currently attributed (Baker \& Rowe, 1990; Smith \& Kroh, 2011) to the genus Heterobrissus: H. niasicus (Doderlein, 1901), H. hemingi (Anderson in Alcock, 1902), H. gigas Baker et Rowe, 1990 and H. erinaceus Baker et Rowe, 1990; all of them inhabit deep muddy bottoms in the Indo-Pacific. The genus Archaeopneustes Gregory, 1892 was originally distinguished from Heterobrissus by the position of the periproct and by the extension of the labrum (Mortensen, 1950), characters which prior to this study were unclear in $H$. montesi, due to the poor preservation of the available fossil material. According to Smith \& Kroh (2011) and Kroh \& Mooi (2019), Archaeopneustes hystrix (Agassiz, 1880 ), today living in the Caribbean area, could belong to Heterobrissus. Also Pygospatangus Cotteau, 1890 , from the ?Eocene and the Late Oligocene of Spain, is considered as a possible junior synonym with Heterobrissus by Smith \& Kroh (2011).

The uncertainty about the relationships existing between these genera was a result of the poor preservation of the holotype of $H$. montesi, which missed the oral face (Manzoni \& Mazzetti, 1878, p. $354-355$, fig. 2), and of the other specimens from the type-area subsequently described by Manzoni $(1879,1880)$ and Stefanini (1908). Also, the preservation of the holotype of Pygospatangus salvae is too poor (Cotteau, 1890, p. 17-18, pl. 14, fig. 1-3) to make any detail about the apical disc, the structure of the plastron, the peristome and tuberculation, so that the true affinities of this taxon cannot, so far, be determined (Smith \& Kroh, 2011).

The aim of this paper was to complete the description of the diagnostic characters of the genus Heterobrissus, based on the re-examination of the original fossil material studied by Manzoni (1879, $1890)$ and Stefanini (1908) and on the study of unreported topotypic specimens from Emilia-Roma- gna and of well preserved specimens recently collected from the Early Miocene of Sardinia. The relationships between Heterobrissus and the closely related genera have been discussed using unreported specimens from the Oligocene of Alicante (Spain) and Recent specimens of H. niasicus, with emphasis on the oral plate structure, a morphological character of major relevance in the systematic of spatangoids.

\section{MATERIAL AND METHODS}

\section{Study area}

The newly reported material of $H$. montesi was collected in the Langhian Pantano Formation from 6 different localities of the Emilia-Romagna Region (Northern Apennines; Fig. 1): Montese (the typelocality), Pescale, Zocca and Guiglia (Province of Modena), Monte Valestra (Reggio Emilia) and Jano near Sasso Marconi (Bologna). The holotype, a poorly preserved specimen, is missing at the Museo di Paleobiologia, University of Modena (MPUM), where the Mazzetti's collection is housed. Specimen numbers prefixed IGF are housed at the Museo di Storia Naturale, Sezione di Geologia e Paleontologia, University of Firenze. They consist of 12 specimens studied by Stefanini (1908) and 5 specimens collected by one of the authors (E.B.). None of the specimens figured in Manzoni (1979) has been traced at the IGF; two specimens illustrated in Stefanini (1908: pl. 14 figs. 4a,b, missing the oral face, and pl. 14, fig. 5, missing the aboral face) are available to study. The oral plating scheme has been taken from IGF.100335 (Jano) and IGF.101266.

Thirty-seven specimens of Heterobrissus collected by one of the authors (P.S.) from the Early Miocene of Sardinia (Arbus, Isili, Nureci and Genoni) were examined at the Museo di Storia Naturale "Aquilegia" of Masullas (MAC) and at the Museo di Paleontologia e Geologia Domenico Lovisato, University of Cagliari (MDLCA); thirty of them from the Early Burdigalian of the Nurallao formation of Isili (MDLCA.23788, MDLCA. 23789, MDLCA.23790, MDLCA 23792, MAC.PL1509, PL1847, PL1860-70, PL2097, PL2165-73), four from the Burdigalian-Early Langhian Marne di Gesturi formation of the NureciGenoni area (MAC.PL2871-3, MDLCA 23791), 
two from the same formation of Genoni (MAC.PL2095-6), one (MAC.PL2163) from the Late Oligocene-Early Aquitanian of Calada Bianca, near Funtanazza.

The holotype of $H$. formai Airaghi, 1901 is wanting at the Museo Regionale di Storia Naturale of Torino (MTPL); the observations reported by Stefanini (1908), who examined that specimen, have been utilised in the discussion.

The holotype of Pygospatangus salvae is housed at the Muséum National d'Histoire Na- turelle, Paris (MNHN, repository code R62327). Ten specimens from the Oligocene (Late Chattian) of Xorret de Catì and Sierra de Monteagudo, near Novelda, Alicante (Spain), were examined in five private Spanish collections: Leonardo Hernandez (LH.01, 04), Clifford Saint Clair (CP.01-03) and Jose Carlos Saldaña (JS.01-02) from Alicante, Carlos Garcia (CG.01-02) from Madrid and Manuel Adel Alegre (MA.01) from Vinaròs. One of these specimens (CG.02) retains a number of primary spines.

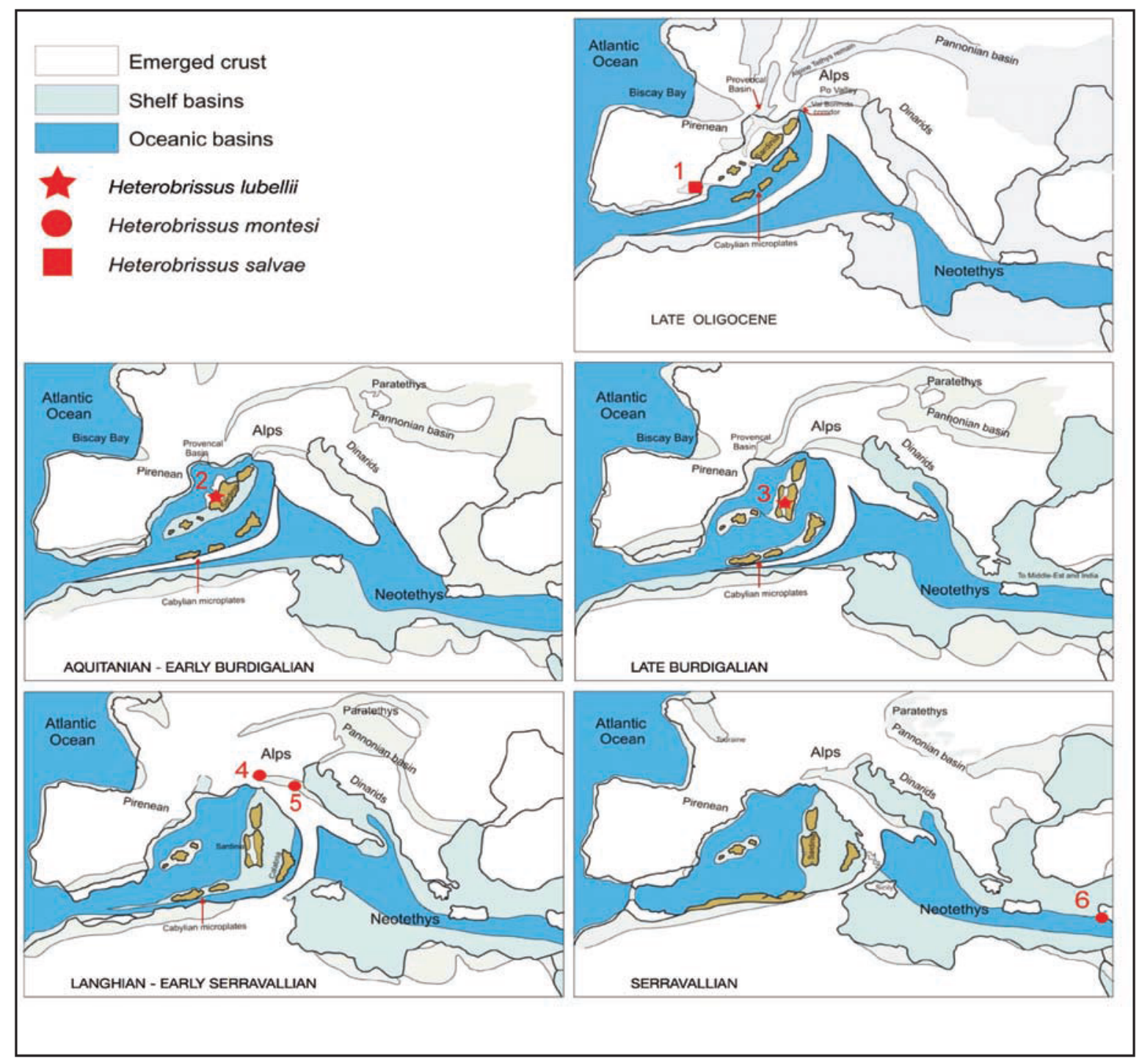

Figure 1. Location map of the Heterobrissus-bearing localities (partially modified from Rosenbaum et al., 2002 and Stara \& Rizzo, 2013). 1: Alicante (Spain), Oligocene; 2: Funtanazza (Sardinia), Late Oligocene-Early Aquitanian; 3: Isili and Nureci (Sardinia), Burdigalian; 4: Pino Torinese (Piedmont), Langhian; 5: Guiglia, Montese, Monte Valestra, Pescale, Rocca Malatina, Jano and Zocca (Emilia-Romagna), Langhian; 6: Alessa near Limossol (Cyprus), Serravallian. 
Six Recent specimens of $H$. niasicus from the Southern China Sea and the Philippines (MAC IVM203, 291-293, 446-448) and one of Archaeopneustes hystrix from Florida (Museum of Comparative Zoology, Harvard University, MCZ ECH-7813) were utilised in the discussion.

Systematic palaeontology follows Smith \& Kroh (2011) and Kroh \& Mooi (2019).

ABBREVIATIONS (used in Fig. 2, Tables 13). $\mathrm{Fm}=$ Formation (formalised); L1 = periproct height; L2 = periproct width; L3 = distance between the lower margin of the periproct and the test base;
$\mathrm{L} 4=$ anterior paired petal length (measure from the apical system to the last plate bearing pores); L5 = anterior paired petal width (measured at midlength); $\mathrm{L} 6=$ posterior paired petal length; $\mathrm{L} 7=$ posterior paired petal width; L8 = distance between the frontal genital pores and the posterior test margin; $\mathrm{L} 9=$ distance between the tip of the labrum and the anterior test margin; $\mathrm{L} 10=$ labrum length; $\mathrm{L} 11=$ sternal plates length. TL, TW, TH $=$ respectively, length, width and height of the test.

CONVENTIONS: in the Tables $1-3$, TL is reported in $\mathrm{mm}$, the other data are expressed as \% of
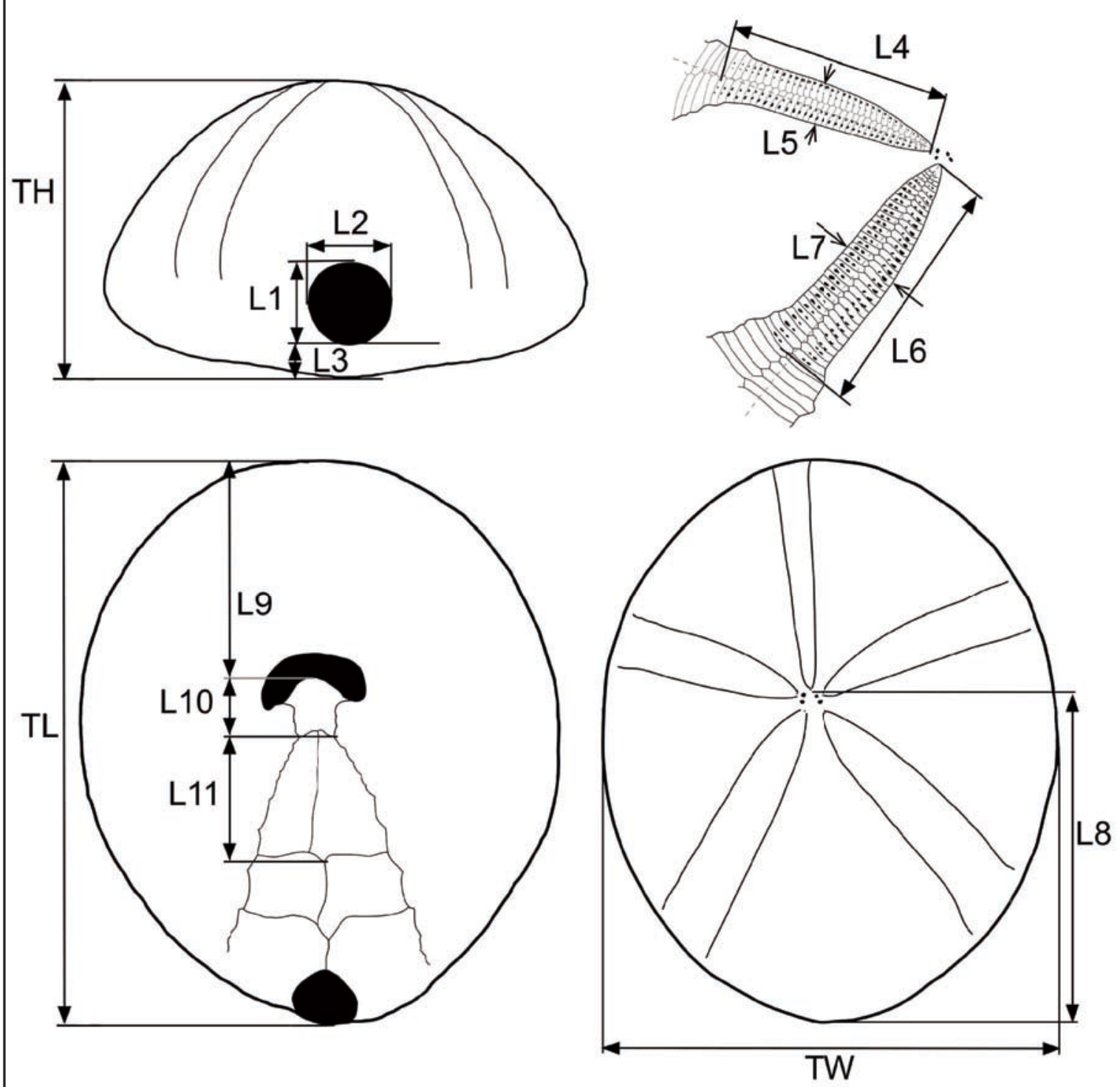

Figure 2. Scheme of the biometric measurements taken from the studied specimens. 


\begin{tabular}{|c|c|c|c|c|c|c|c|c|c|c|c|c|c|c|}
\hline $\begin{array}{l}\text { Heterobrissus } \\
\text { montesi }\end{array}$ & TL & TW & TH & L1 & L2 & L3 & L4 & L5 & L6 & L7 & L8 & L9 & L10 & L11 \\
\hline IGF 101266 & 116 & 80 & & & & 0 & & & & & & 33 & 10.5 & 25 \\
\hline IGF 101267 & 102 & 86.5 & & 10 & 8 & 0 & & & & & & 28.5 & 11 & 22.5 \\
\hline IGF 100345 & 104 & 74 & & & & 0 & 42.5 & 10 & 47 & 11 & 56 & & & \\
\hline IGF 100346 & 101 & 77 & & & & 0 & 46 & 10 & 50 & 12 & & & & \\
\hline IGF 101268 & 90 & 96.5 & & & & 0 & & & & & & & & \\
\hline IGF.100335 & 86 & & & 11.5 & 11.5 & 0 & & & & & & & & \\
\hline $\begin{array}{l}\text { Stefanini (1908) } \\
\text { pl. 14, fig. } 4\end{array}$ & 98 & 90 & 40 & & & & 46 & 10.5 & 51 & 12 & 55 & & & \\
\hline $\begin{array}{l}\text { Stefanini (1908) } \\
\text { pl. 14, fig. } 5\end{array}$ & 102 & 79.5 & & 9 & 7.5 & & & & & & & 36.5 & & \\
\hline $\begin{array}{l}\text { Stefanini (1908) } \\
\text { specimen II }\end{array}$ & 123 & 83.5 & 40.5 & & & 0 & & & & & 56 & 31 & & \\
\hline $\begin{array}{l}\text { Stefanini (1908) } \\
\text { specimen III }\end{array}$ & 108 & 85 & & & & & & & & & 56.5 & & & \\
\hline $\begin{array}{l}\text { Stefanini (1908) } \\
\text { specimen IV }\end{array}$ & 99 & 89 & & & & & & & & & 54.5 & & & \\
\hline Mean values & 102.5 & 84 & 40.5 & 10 & 9 & 0 & 45 & 10 & 49.5 & 11.5 & 55.5 & 32.5 & 11 & 24 \\
\hline $\begin{array}{l}\text { Heterobrissus } \\
\text { lubellii sp. nov. }\end{array}$ & TL & TW & TH & L1 & L2 & L3 & L4 & L5 & L6 & L7 & L8 & L9 & L10 & L11 \\
\hline MDLCA 23788 & 112 & 77 & 57 & 14 & 12 & 0 & 52 & 13,5 & 55 & 17 & 54 & 38 & 11 & 25 \\
\hline MDLCA 23789 & 109 & 84 & 51 & & & & 49.5 & 12 & 60.5 & 14 & 60 & 38 & 9.5 & 22.5 \\
\hline MDLCA 23790 & 105 & 92 & 45 & & & 0 & 55 & 13 & 63 & 14 & 55 & 37 & & \\
\hline MDLCA 23791 & 117 & 90 & 49 & 19 & 12 & 0 & & 13 & 56 & 15 & 53 & 36 & 10 & 22 \\
\hline MAC PL1504 & 94 & 76.5 & 48 & 9 & 7.5 & 0 & 53 & 14 & 60 & 16 & 66 & 37 & & \\
\hline MAC PL1505 & 103 & 92 & 49.5 & 15.5 & 14.5 & 0 & 45.5 & 13 & 66 & 14.5 & 53 & 37 & 11 & \\
\hline MAC PL1506 & 108 & 83 & 50 & 16 & 12.5 & 0 & 51 & 12 & 54 & 15 & 45 & 35 & 11 & \\
\hline MAC PL1508 & 115 & 80 & 38 & 11 & 11 & 0 & 48 & 12 & 56 & 16 & 53 & 35 & 8 & 25 \\
\hline MAC PL1860 & 121 & 77 & 48 & 11 & 9 & 0 & 49.5 & 11 & 54.5 & 12 & 56 & & & \\
\hline MAC PL1861 & 115 & 83 & 45 & 12 & 10 & 0 & 49 & 13 & 56.5 & 15 & 61 & & & 25 \\
\hline MAC PL1862 & 104 & 90 & 55 & & & 0 & 55 & 13 & 56 & 13 & 53 & 34 & 9 & \\
\hline MAC PL1864 & 103 & 69 & 47 & & & & 45 & 13.5 & 51 & 13.5 & 57 & 37 & 11 & 23 \\
\hline MAC PL1872 & 110.5 & 91 & 47 & & & & 54 & 12 & 61.5 & 14 & 61 & & & \\
\hline MAC PL1873 & 127 & 83 & 32 & & & & & 10 & & 14 & 53 & & & \\
\hline MAC PL2095 & 125 & 82 & 36 & & & 0 & 43 & 11 & 56 & 13 & 65 & 38.5 & 11.5 & 20 \\
\hline MAC PL2096 & 110 & & 55 & & & 0 & 47 & 13 & 55 & & & & & \\
\hline MAC PL2097 & 96 & 88.5 & 49 & 13.5 & 12.5 & 0 & & & & & 63 & 38 & 10 & 21 \\
\hline MAC PL2163 & 91 & 88 & 34 & & & 0 & 41 & 10 & 52 & 12 & 58 & 37 & 9 & \\
\hline Mean values & 109 & 84 & 46 & 13.5 & 11 & $\mathbf{0}$ & 49 & 12.5 & 57 & 14 & 57 & 37 & 10 & 23 \\
\hline $\begin{array}{l}\text { Hetrobrissus } \\
\text { salvae }\end{array}$ & TL & TW & TH & L1 & L2 & L3 & L4 & L5 & L6 & L7 & $\mathbf{L 8}$ & L9 & L10 & L11 \\
\hline $\begin{array}{l}\text { Holotype } \\
\text { MNHN.F.R62327 }\end{array}$ & 84 & 84.5 & 56 & 16.5 & 15.5 & 5 & & & & & & & & \\
\hline LH.01 & 80 & 85.5 & 46 & & & 0 & 45.5 & 10 & 46.5 & 11 & 62 & 32.5 & 10 & \\
\hline LH.04 & 72 & 87.5 & 51 & & & & 48 & & 51 & & & & & \\
\hline CP.01 & 75 & 85 & & & & & 46 & 9 & 49 & 10.5 & & & & \\
\hline CP.02 & 80 & 80 & 54 & 16.5 & 14.5 & 2 & 47.5 & 9.5 & 50 & 10 & & 34 & & \\
\hline CP.03 & 55 & 85 & & & & & 48.5 & 9.5 & 52 & 11 & & 34 & 10.5 & 26 \\
\hline JS.01 & 75 & 82 & 46.5 & 13.5 & 16 & 1 & 44 & 10.5 & 46 & 11.5 & 61 & 32 & 11.5 & 27 \\
\hline CG.01 & 62 & 86.5 & & 17.5 & 16 & 3 & & 10 & & 11 & 66 & 31 & 9 & 30 \\
\hline MA.01 & 69 & 80 & & & & & & & & & & 34 & 11.5 & 26 \\
\hline Mean values & 72.5 & 84 & 50.5 & 16 & 15.5 & 2 & 46.5 & 10 & 49 & 11 & 63 & 33 & 10.5 & 27.5 \\
\hline
\end{tabular}




\begin{tabular}{|c|c|c|c|c|c|c|c|c|c|c|c|c|c|c|}
\hline species & TL & TW & TH & L1 & L2 & L3 & L4 & L5 & L6 & L7 & L8 & L9 & L10 & L11 \\
\hline $\begin{array}{l}\text { Heterobrissus } \\
\text { montesi }\end{array}$ & 102.5 & 84 & 40.5 & 10 & 9 & 0 & 45 & 10 & 49.5 & 11.5 & 55.5 & 32.5 & 11 & 24 \\
\hline $\begin{array}{l}\text { Heterobrissus } \\
\text { lubellii sp. nov. }\end{array}$ & 109 & 84 & 46 & 13.5 & 11 & 0 & 49 & 12.5 & 57 & 14 & 57 & 37 & 10 & 23 \\
\hline $\begin{array}{l}\text { Heterobrissus } \\
\text { salvae }\end{array}$ & 72.5 & 84 & 50.5 & 16 & 15.5 & 2 & 46.5 & 10 & 49 & 11 & 63 & 33 & 10.5 & 27.5 \\
\hline $\begin{array}{l}\text { Heterobrissus } \\
\text { hystrix }\end{array}$ & 127 & 82 & 50.5 & 12.5 & 13.5 & 6 & - & 8 & - & 9.5 & 54.5 & 35 & 10.5 & 23 \\
\hline \multicolumn{15}{|l|}{2} \\
\hline $\begin{array}{l}\text { Echinopneustes } \\
\text { niasicus }\end{array}$ & TL & TW & TH & L1 & L2 & L3 & L4 & L5 & L6 & L7 & L8 & L9 & L10 & L11 \\
\hline MAC IVM291 & 121 & 77.5 & 53 & 14 & 12.5 & 11 & 45 & 10 & 48.5 & 7.5 & 61 & 43 & 9.5 & 22 \\
\hline MAC IVM292 & 124 & 80 & 46 & 14 & 12.5 & 9 & 43 & 7.5 & 46 & 9 & 57 & 44 & 9.5 & 23.5 \\
\hline MAC IVM293 & 105.5 & 79.5 & 51 & 14 & 12.5 & 6 & 50.5 & 11.5 & 57 & 12 & 51.5 & 44 & 10.5 & \\
\hline MAC IVM446 & 137 & 80 & 51 & 15 & 11.5 & 8 & 46.5 & 9 & 46 & 9.5 & 53 & 40 & 10 & 21 \\
\hline MAC IVM447 & 114 & 80 & 55 & 14 & 14.5 & 6.5 & 51.5 & 11.5 & 56 & 11.5 & 55 & 42 & 9 & 20 \\
\hline MAC IVM448 & 93 & 77.5 & 56 & 13 & 13 & 12 & 47.5 & 10 & 48.5 & 12 & 55 & 43 & 10.5 & 21.5 \\
\hline Mean values & 116 & 79 & 52 & 14 & 13 & 9 & 47.5 & 10 & 50.5 & 10.5 & 55.5 & 42.5 & 10 & 21.5 \\
\hline
\end{tabular}

Table 2. Species of the genus Heterobrissus Manzoni et Mazzetti, 1878. Mean biometric values in the studied samples. Measures of TL in mm, the other biometric data expressed as \% of TL. Table 3. Echinopneustes niasicus (Doderlein, 1901), Recent. Indo-Pacific. Measures of TL in mm, the other biometric data expressed as \% of TL.

TL. In the plating schemes, the plates are numbered according to Lovén's system (Lovén, 1874), the interambulacral zones are shaded grey, ambulacra unshaded.

\section{Finding localities}

The Bismantova Group (Northern Apennines) consists of the Pantano Fm and the Cigarello Fm (Amorosi et al., 1993). The Pantano Fm deposited during the Late Burdigalian-Langhian (Bettelli et al, 1989; Panini et al., 2005). The upper limit with the overlying Cigarello Fm is dated to the Langhian, within the Praeorbulina glomerosa zone and the lower part of the Orbulina suturalis-Globorotalia peripheroronda zone (Amorosi et al., 1996). Most of the specimens of Heterobrissus described in Manzoni (1880) and Stefanini (1908) were collected from siltstones overlying the Calvenzano Member at Jano and San Leo, near Sasso Marconi (Bologna). They belong to the upper part of the Pantano Fm that in that area has been dated to the Langhian and represents the deposition in an outer shelf setting (Panini et al., 2005). Also at Monte
Valestra (Reggio Emilia province) the most frequent lithology consists of grey sandy siltstones, alternating with stratified arenites. The echinoids, commonly deprived of spines and randomly oriented, are rather frequent within the graded arenite, representing low-energy resedimentation events from shallower settings. Heterobrissus is commonly associated with Mazettia pareti (Manzoni, 1879) and Toxopatagus italicus (Manzoni \& Mazzetti, 1878) (see Borghi, 2012, 2013 and Stara \& Borghi, 2012, for an overview).

The main Heterobrissus-bearing deposits examined in Sardinia belong to the Nurallao formation, which is represented at the base by the Duiddure member, made of coarse clasts from transitional (deltaic) environments, and of the overlying marine deposits of the Arenarie di Serralonga member, dated to the Aquitanian-Early Burdigalian (Sowerbutts \& Underhill, 1998). At Isili (Cagliari province), four specimens attributed to $H$. montesi were recorded from the upper part (Early Burdigalian) of the Arenarie di Serralonga (Stara et al., 2012); 26 additional specimens have been recently collected from this locality by one of the authors 
(P.S.). At Isili, Heterobrissus was collected from two different outcrops, located near Baraci and Nuraghe Longu; the second outcrop is stratigraphically lower. At Baraci, Heterobrissus is associated with Sardospatangus, Opissaster sp., Ova ?karreri (Laube, 1869); Ova sp., Amusium sp., Faorina maullui Stara et Borghi, 2012; at Nuraghe Longu, with Sardospatangus, Opissaster sp., Ova ?karreri; Ova sp., Mariania comaschicariae Stara, Borghi et Kroh, 2016; Faorina orbignyi (Cotteau, 1877), Schizobrissus sp. and Clypeaster sp. Heterobrissus is present in Sardinia also at Funtanazza, in a Late Oligocene to Late Aquitanian deposit (Annino et al., 2000), belonging to the unit E described in Assorgia et al. (1992), precisely in the Calada Bianca sub area (Late Oligocene to Early Aquitanian) described in Mancosu \& Nebelsick (2016), and at Nureci and Genoni, in the Burdigalian-Early Langhian Marne di Gesturi formation (Assorgia et al., 1995).

The holotype of Pygospatangus salvae Cotteau (1890) was originally reported from the Eocene of Callosa (Alicante Province, Spain). However, this attribution is doubtful since all subsequent citations of this species were Oligocene in age (López \& Sillero, 2006; Smith \& Kroh, 2011). Also the specimens under study from Monteagudo, near Novelda (Alicante, Spain), were collected from sediments dated by micropaleontological analyses (Azema et al., 1969) to the Late Oligocene (Chattian), possibly also to the Early Aquitanian. The sediments, consisting of limestones alternating with marls, belong to the transgressive phase occurred at the Oligocene-Miocene boundary (Mapa Geologico de Espana, 1:50000, sheets 848 and 871).

\section{RESULTS}

The study of the fossil material of $H$. montesi from the type-area enables to describe previously unknown morphological features in the type-species, thus completing the list of the diagnostic characters in the type-species of the genus Heterobrissus. The specimens examined from the Early Miocene of Sardinia share the distinctive features listed in the following and, since they are better preserved on average, some illustrations are taken from them. - Test ovate in outline with convex anterior and weakly pointed posterior (Fig. 3).
- Shell rather thin aborally; the plastron and the ambitus are more robust, with a maximum thickness of about 2-3 $\mathrm{mm}$ in correspondence of the sternal plates and around the periproct.

- Posterior face short and undercut, sometimes almost facing downwards (Figs. 9, 14).

- The apical system is ethmolytic, with four gonopores, the anterior pores placed closer to one another than the posterior pair. It corresponds to the scheme provided by Mortensen (1950, fig. 147) for Archaeopneustes hystrix.

- Frontal ambulacrum flush over the aboral surface, becoming slightly depressed only as it approaches the peristome; the pores are double in the upper part of the ambulacrum, farther down they are reduced to a narrow slit (Fig. 12).

- No occluded plates are present at the end of the paired petals (Fig. 10).

- Pores in the outer columns drop-shaped and larger than those in the inner columns (Fig. 11).

- Adorally, the ambulacra are strongly developed into conspicuous phyllodes (Figs. 8, 13): there are 7-8 unipores with a large periporal area in each column of the ambulacrum III, 10-12 in the lateral ambulacra II and IV (Fig. 13).

- The labral plate extends to half-way along the third plate in the adjacent ambulacral columns (Figs. 13, 19).

- Sternal, episternal and post episternal plates almost symmetrical, opposite rather than alternate and not indented by the ambulacral plates. The sternals extend to the adjoining ambulacral plates 9-10. Plates 5.a.4 and 5.b.4 are "L" shaped (Figs. 4, 13, 19).

- The structure of the plates in the oral interambulacra 1, 2, 3, 4 is amphiplacous. (Figs. 4, 13).

- Periproct inframarginal to almost oral (Figs. 4, 9, 14), framed by the plates 5.a.4, 5.b.4 to 5.a.7, 5.b.7 (Figs. 4, 13, 19).

- Primary spines finely striate longitudinally, with a hollow lumen and circular section.

- Fascioles absent (at least in all the specimens with TL $>38 \mathrm{~mm}$ ).

\section{DISCUSSION}

\section{The sample from Sardinia}

As seen above, the specimens examined from the Early Miocene of Sardinia share all the main 


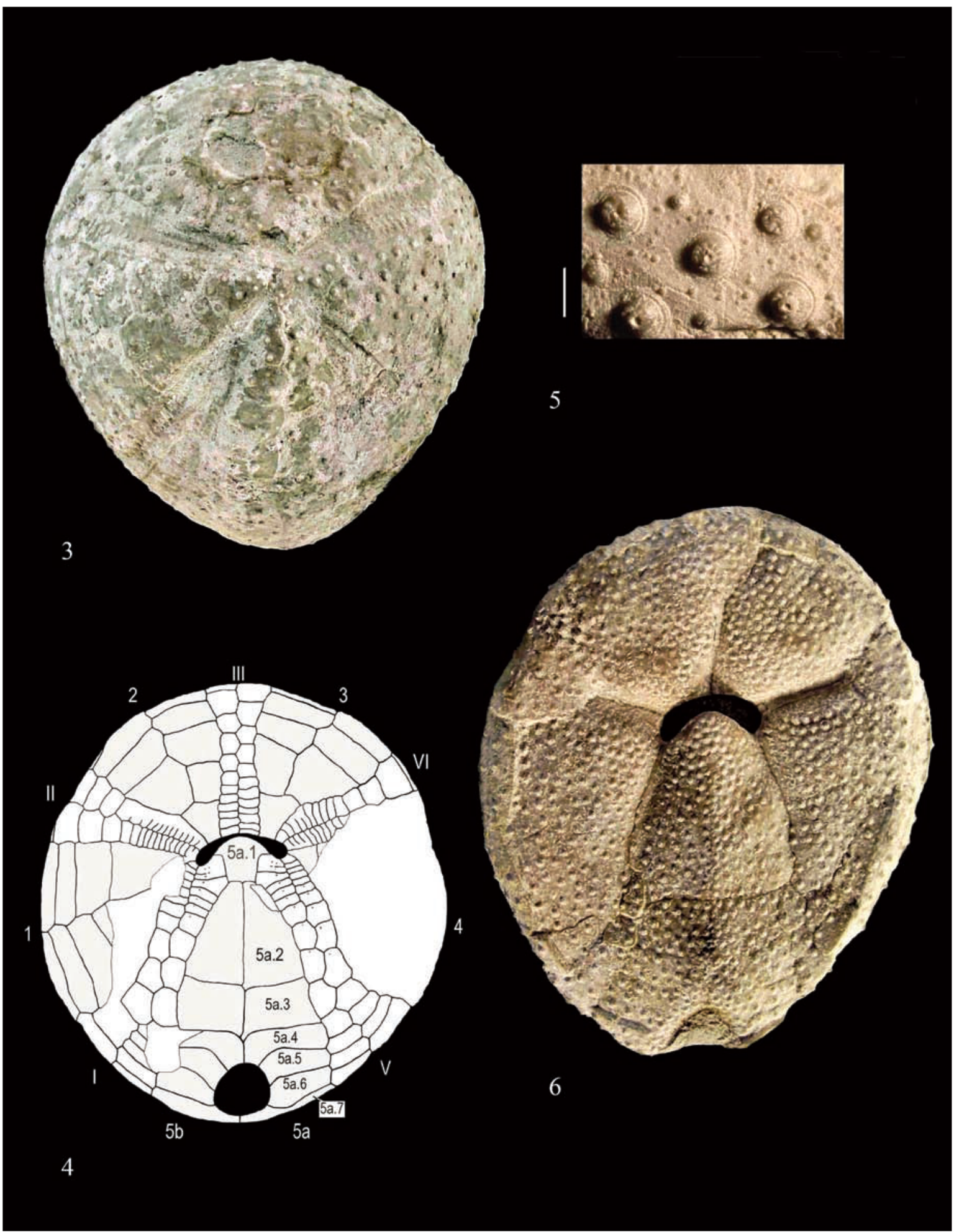

Figures 3-6. Heterobrissus montesi Manzoni et Mazzetti, 1878, Langhian of Emilia-Romagna. Fig. 3: aboral view of IGF.104267, a specimen figured in Stefanini (1908, pl. 14, figs. 4a,b), TL $=98 \mathrm{~mm}$, Jano (Bologna). Fig. 4: oral plating diagram taken from IGF.100335, Jano. Fig. 5: close up of the primary tubercles at the ambitus in the aboral interambulacrum 4, taken from IGF.101267, Monte Valestra (Reggio Emilia). Fig. 6: oral view of IGF.101266, TL =116 mm, Monte Valestra. The scale bar equals $1 \mathrm{~mm}$. 


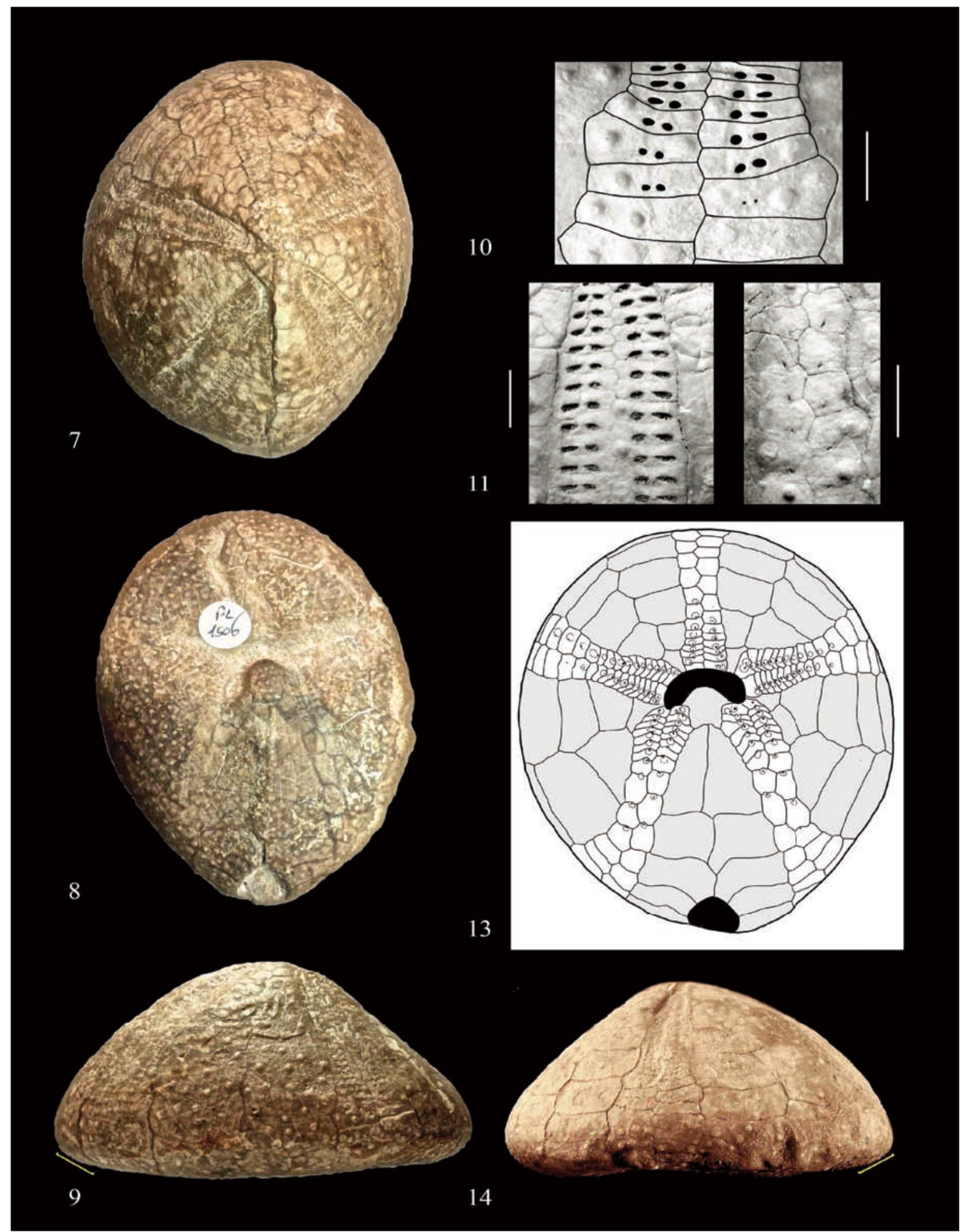

Figures 7-14. Heterobrissus lubellii n. sp., Early Miocene of Sardinia. Figs. 7-9: respectively aboral, oral and lateral views of the holotype (MDLCA.23788), TL = $112 \mathrm{~mm}$, Burdigalian, Isili. Figs 10-12: MAC.PL1505, Burdigalian, Isili: close up view of the tip of a petal (Fig. 10), of the mid part of the aboral ambulacrum IV (Fig. 11) and of the frontal ambulacrum III (Fig. 12); the scale bars equal 5 mm. Fig. 13: oral plating diagram of MAC.PL2097, Early Burdigalian, Baraci. Fig. 14: lateral view of MAC.PL1504, TL $=94 \mathrm{~mm}$, Burdigalian of Isili; the yellow bars indicate the position of the periproct in lateral view. 


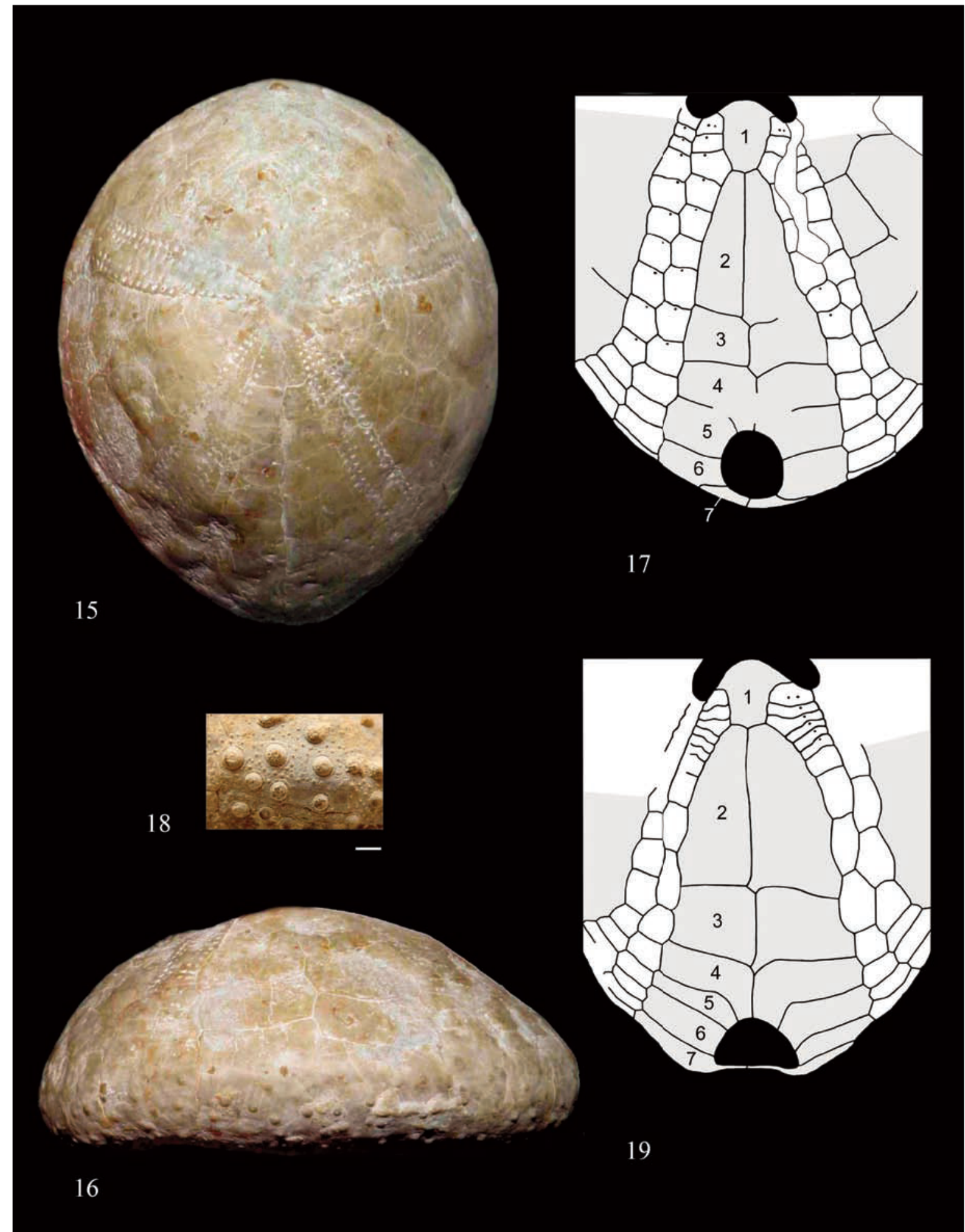

Figures 15-18. Heterobrissus salvae (Cotteau, 1890), Late Oligocene of Monteagudo, near Novelda (Spain). Figs. 15-16: aboral and lateral views of LH.02, TL $=95 \mathrm{~mm}$. Fig. 17: plastron plating in JS.01. Fig. 18: close up of primary tubercles in the aboral interambulacrum 4 at the ambitus, in CG.01. The scale bar equals $1 \mathrm{~mm}$. Figure 19. Heterobrissus montesi Manzoni et Mazzetti, 1878: plastron plating taken from IGF.101266, TL $=116 \mathrm{~mm}$, Langhian of Monte Valestra, near Reggio Emilia. 


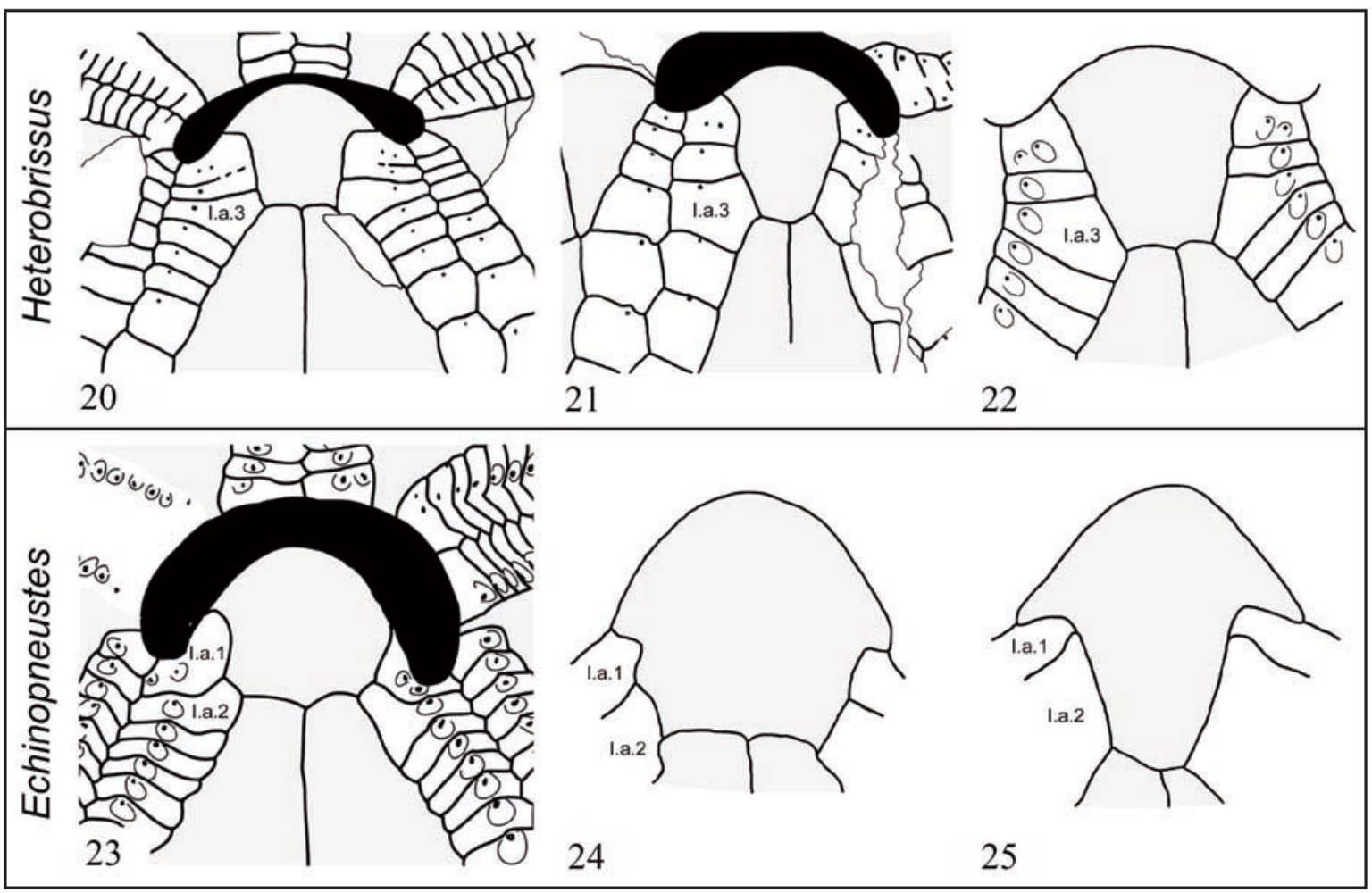

Figures 20-25. Plating schemes of the peristome area highlighting the extension of the labrum. Fig. 20: Heterobrissus montesi Manzoni et Mazzetti, 1878; Fig. 21: Heterobrissus salvae (Cotteau, 1890); Fig. 22: Heterobrissus hystrix (Agassiz, 1880), from Mortensen (1950): Fig. 23: Echinopneustes niasicus (Doderlein, 1901); Fig. 24: Echinopneustes gigas (Baker et Rowe, 1990); Fig. 25: Echinopneustes erinaceus (Baker et Rowe, 1990).

morphological features with the fossils from the Northern Apennines. Stara et al. (2012) assigned eight specimens from Baraci to Heterobrissus montesi. However, the availability for this study of a better preserved sample from a stratigraphically more differentiated area showed that the specimens from Sardinia differ from $H$. montesi by longer and larger petals, peristome farther from the anterior margin of the test, larger periproct and more elevate test (Table 2). Therefore, they are herein assigned to a new species, Heterobrissus lubellii $\mathrm{n}$. sp.

\section{Comparison with other genera}

Gregory (1892) based the genus Archaeopneustes on the Recent species Palaeopneustes hystrix A. Agassiz, 1880 (Figs. 27, 31) without considering its differentiation from the pre-existing genus Heterobrissus Manzoni et Mazzetti, 1878.

The distinction of Archaeopneustes was confirmed by Mortensen (1950): "the labrum extending to the third adjoining ambulacral plate, not to the second as in Heterobrissus", and by a slightly more inframarginal periproct. But the plate structure in $H$. montesi was still unknown at that time, as well as the apical system (Stefanini, 1908). Mortensen (1950) based his concept of Heterobrissus on an Indo-Pacific species, $H$. niasicus, which differs from the western Atlantic $A$. hystrix in the ways described. The topo-typic material under study indicates that $H$. montesi has an inframarginal periproct and an elongate labrum that extends to the third ambulacral plate, thus sharing the main diagnostic features of Archaeopneustes and confirming the synonymy of the two genera, as already suggested by Smith \& Gale (2009) and Kroh \& Mooi (2019).

Mortensen (1950, p. 200) affirmed also that "If the character of the labrum (in $\mathrm{H}$. montesi) should prove ultimately to agree with Archaeopneustes hystrix, then I do not see how it could be avoided to regard Archaeopneustes as a synonym of Heterobrissus, but it might then be desirable to create 
a new genus for the species niasicus...". According to this sentence, H. niasicus (Döderlein, 1901) is here transferred into Echinopneustes n. gen. The main morphological characters distinguishing Echinopneustes from Heterobrissus are (Table 4): the labrum reaching only the middle plate 2 of the adjoining ambulacra (Fig. 23), not plate 3 as in Heterobrissus (Figs. 20, 22); the peristome farther from the anterior test margin (mean L9>38\% TL); periproct marginal (Figs. 30, 37; mean L3 $\geq 9 \% \mathrm{TL}$ ), commonly not visible in oral view (Figs. 28, 35) and bounded by the fifth plates in the interambulacrum 5 , whereas the periproct is inframarginal to almost oral (L3 $\leq 6 \% \mathrm{TL})$ and framed adorally by the fourth plates, in Heterobrissus. Additionally, in Echinopneustes gen. nov. the test outline is commonly less constricted posteriorly (Figs. 28, 35) and the posterior face is not, or only slightly, undercut (Fig. 36). Heterobrissus erinaceus Baker et Rowe, 1990 and H. gigas Baker et Rowe, 1990 share these diagnostic characters (Figs. 24-25) with $E$. niasicus, consequently, they are transferred into the new genus. After Kohler (1914) in H. hemingi (Anderson, 1902) the labrum extends only "to the margin of the first adjoining ambulacral plate"; however, since Kohler did not provide a scheme and no specimens are available to study this rare species, its generic attribution is left open.
Mortensen (1950) noticed that in E. niasicus the primary spines are flattened and densely thorny and the ophicephalous pedicellariae are numerous, while in $H$. hystrix the primary spines are smooth and roundish and ophicephalous valves are lacking. However, spines in Echnopneustes are heterogeneous, since $E$. erinaceus has numerous fine and short spines and even in E. niasicus the spines may have sometimes a roundish section, with fine thorns. The difference regarding the ophicephalous pedicellariae is valid for the extant species belonging to these two genera (including also $E$. erinaceus and E. gigas, Table 4), but these minute morphological particulars are not preserved in the fossil material thus preventing comparison.

Pygospatangus Cotteau, 1890 is similar to Heterobrissus, but relevant characters of the oral face and the apical disc in the type species have so far remained unknown (Smith \& Kroh, 2011). Newly reported material from the Oligocene of Novelda (Spain; Figs. 15-17, 18, 21, 29, 33) allows to illustrate the structure of the plastron (Fig. 17), which was not visible in the holotype (MHNM R62327), the sole specimen described by Cotteau (1890: p. 17, pl. 14, fig. 13). The test outline is ovate with convex anterior and weakly pointed posterior (Figs. 15, 29). The oral face is flat, the

\begin{tabular}{|c|c|c|c|c|c|c|c|}
\hline \multirow[b]{2}{*}{ Morphological characters } & \multicolumn{4}{|c|}{ Heterobrissus } & \multicolumn{3}{|c|}{ Echinopneustes } \\
\hline & 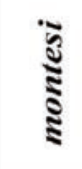 & 今̀ & $\stackrel{\Xi}{\Sigma}$ & $\begin{array}{l}\cong \\
\vdots \\
\vdots \\
\vdots\end{array}$ & 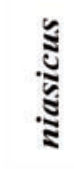 & 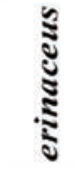 & s. \\
\hline $\begin{array}{l}\text { Labral plate extending to the ambulacral plate } 2 \\
\text { " " }\end{array}$ & 3 & 3 & 3 & 3 & 2 & 2 & 2 \\
\hline $\begin{array}{l}\text { Distance of the peristome from the anterior margin: } \\
\text { mean } \mathrm{L} 9>38 \% \mathrm{TL} \\
\text { mean } \mathrm{L} 9<37 \% \mathrm{TL}\end{array}$ & 32.5 & 35 & 33 & 37 & 42.5 & 38.7 & 38.3 \\
\hline $\begin{array}{l}\text { Periproct marginal, mean } \mathrm{L} 3 \geq 9 \% \mathrm{TL} \\
\text { " } \quad \text { inframarginal, mean L3 } \leq 6 \% \mathrm{TL}\end{array}$ & 0 & 6 & 2 & 0 & 9 & $\mathrm{x}$ & $\mathrm{x}$ \\
\hline $\begin{array}{lll}\text { Periproct bounded adorally by plates } 5 . a .5 \text { and } 5 . b .5 \\
\text { " } & \text { " } & 4 . a .4 \text { and } 4 . \text { b. } 4 \\
\end{array}$ & $\mathrm{x}$ & $\mathrm{x}$ & $\mathrm{x}$ & $\mathrm{x}$ & $\mathrm{x}$ & & \\
\hline $\begin{array}{l}\text { Ophicephalous pedicellariae present } \\
\text { " } \quad \text { absent }\end{array}$ & & $\mathrm{x}$ & & & $\mathrm{x}$ & $\mathrm{x}$ & $\mathrm{x}$ \\
\hline
\end{tabular}

Table 4. Main morphological features distinguishing the genus Heterobrissus Manzoni et Mazzetti, 1878 from Echinopneustes n. gen. 
apical disc is ethmolytic and corresponds to the scheme provided by Lopez \& Sillero (2006; figs. $241 \mathrm{~B}-\mathrm{C})$, the labral plate always extends to the third adjacent ambulacral plate (Fig. 21), the oral interambulacra 1-4 are amphiplacous; the oral plates 5.a.4 and 5.b.4 are "L" shaped (Fig. 17). Aborally, in the lateral ambulacra the pore-pairs terminate 3-4 plates above the ambitus and no occluded plates are present distally. The pore-pairs in the ambulacrum III are small and subcircular adapically, elsewhere the pores are in form of small single oblique slits. The pores of the outer columns in the paired ambulacra are drop-shaped and larger than those of the inner columns. Fascioles are absent (Lopez \& Sillero, 2006). The peristome is lunate and rather close to the anterior test margin (Fig. 29; range L9 $=31-34 \% \mathrm{TL}$ ). The periproct is rather large, occupying most of the short and undercut posterior face (Fig. 33). It is marginal, well visible in oral view (Fig. 29) and bounded by four plates on each side (5.a.4 to 5.a.7 and 5.b.4 to 5.b.7; Fig. 17). The oral ambulacra do not indent the posterior interambulacrum. The tuberculation is coarse and heterogeneous and consists of scrobiculate, perforate and crenulate primary and secondary (rare) tubercles and numerous miliares (Fig. 18). Primary spines are slender and longitudinally finely striate; they are $10-15 \mathrm{~mm}$ long in a specimen (CG.03) with $\mathrm{TL}=60 \mathrm{~mm}$. All these features match with those in $H$. montesi. The test in the holotype of $P$. salvae is very thick (up to 8-9 $\mathrm{mm}$ ), as illustrated in Smith \& Kroh (2011). However, in all the other specimens under study the test is relatively thin aborally and, although the thickness increases adorally particularly in the plastron and around the periproct, it is not very different from that in Heterobrissus montesi. Pygospatangus salvae differs from $H$. montesi also by the plates in the proximal part of the oral ambulacra I and V, that are longer and, as a consequence, the sternal plates extend only to the ambulacral plates $7-8$, not to the plates 9-10 as in H. montesi (compare Figs. 17-19). The oral posterior ambulacra lack large primary tubercles from the peristome almost to the margin; however, some specimens of $H$. montesi from the type-area (e.g., IGF.100335) and from Cyprus share the same feature. These differences point to a distinction only at the specific level, consequently this species is here renamed Heterobrissus salvae (Cotteau, 1890), new combination.
Antillaster Lambert, 1909 is known from the Eocene to Miocene of the Caribbean and the Eocene of the Caucasic area (McNamara et al., 2002). The type-species, A. cubensis Cotteau, 1871 , has only 3 gonopores. Kier (1984) revised this genus and separated it into two informal "groups", "pointing to the occurrence of a number of intermediate forms. The oldest group (Eocene-Oligocene) is morphologically more similar to Heterobrissus and shares the presence of four gonopores and the shape of the phyllodes. However, the species belonging to this group differ from $H$. montesi by a more depressed test, oral face convex, not flat, narrower petals extending farther towards the test edge and a different position of the periproct. Occluded plates are always present at the end of the paired petals in all the species of Antillaster in which the plate sutures are visible (Kier, 1984), whereas they are absent in H. montesi and in H. salvae.

The genus Brissolampas Pomel, 1883 was based on Palaeopneustes conicus Dames, 1877, from the Aquitanian of Veneto (Northern Italy). The main characters stated for this species match with those in Heterobrissus but the ambulacrum III is described as "petaloid". Since the sole specimen so far known of this species (Dames, 1877: p. 47, pl. 8 , fig. 1) has the frontal ambulacrum only partially visible, new topotypic material is needed to confirm the separation of this genus from Heterobrissus.

\section{Systematic placement of Heterobrissus and Echinopneustes $\boldsymbol{n}$. gen.}

On account of the ethmolytic apical disc, the petaloid ambulacra (at least adapically) and the amphisternous plastron, Heterobrissus and Echinopneustes are members of the order Spatangoida. Earlier studies attributed Heterobrissus to various families. Mortensen (1950) suggested that Heterobrissus, Archaeopneustes and Pygospatangus should be placed under the Palaeopneustidae. Later on, Heterobrissus and Pygospatangus were placed into the Asterostomatina by Fischer (1966). However, the grouping together of spatangoid taxa that lack fascioles as adults into Mortensen's Palaeopneustidae or Fischer's Asterostomatina has historically been regarded as unsatisfactory (Fischer, 1966; Chesher, 1968). In particular, the attribution to the Asterostomatidae was strongly rejected by the 
results of the cladistic analysis in Stockley et al. (2005, fig. 1): the polyphyletic arrangement of the fasciole-less "asterostomatids" highlighted by both molecular and morphological analyses strongly implied that there were multiple origins for these deepsea spatangoids. Only a few genera originally attributed to the paleopneustids by Mortensen (1950) are today retained in this family (Smith \& Kroh 2011). The Paleopneustidae appear to represent a small clade basal to prenasterids and schizasterids (Stockley et al., 2005; Kroh \& Smith 2010); they are characterized by the lack of a frontal groove, long labral plate extending to the third or fourth ambulacral plate and marginal and/or peripetalous fascioles, at least in juveniles. After Smith \& Kroh (2011) these characters fit well with Heterobrissus and Pygospatangus, which were included in the "Paleopneustina Incertae sedis B". Kroh \& Mooi (2019) actually confirm this location, accepting it as a "temporary name".

One of the major problems in firmly reconstructing relationships between spatangoida lacking fascioles, just as Heterobrissus and Echinopneustes, is the common occurrence of secondary loss of fascioles in adults. Many deep-sea groups appear to have undergone secondary morphological simplification involving the loss of fascioles and/or reduction or complete loss of petals. In fact, fascioles are essential structures for an infaunal mode of life, but they serve no purpose in epibenthic species and are therefore commonly lost in deep sea forms. The absence of petals and fascioles is commonly interpreted as plesiomorphic, but when additional data are available, including the fasciole bearing in juveniles, such absence is recognized as being secondary reversals and a different topology results in cladistic analyses (Stockley et al., 2005). Recent analyses, such as Kroh \& Smith (2010) and Kroh in Stara et al. (2016), based on the matrix proposed by Stockley et al. (2005, p. 21-22), under exclusion of the fasciole characters, resulted in a largely unresolved tree and failed to conclusively resolve the systematic placement of Heterobrissus (represented in the analysis by $H$. hystrix). To fully resolve the placement of Heterobrissus, Echinopneustes and several other atelostomates, additional data on ontogenetic development of fascioles is needed. Unfortunately, no information about the presence of fascioles in juveniles is so far available for the genera under study.

\section{SYSTEMATIC PALEONTOLOGY}

Superordo ATELOSTOMATA von Zittel, 1879

Ordo SPATANGOIDA L. Agassiz, 1840

Subordo PALEOPNEUSTINA Markov et Solovjev, 2001

Familia PALEOPNEUSTINA incertae sedis B (Smith et Kroh, 2011)

Genus Heterobrissus Manzoni et Mazzetti, 1878

Heterobrissus Manzoni \& Mazzetti, 1878, p. 354 , by original designation. [= Pygospatangus Cotteau, 1890, p. 17, type species Pygospatangus salvae Cotteau, 1890, p. 17; = Archaeopneustes Gregory, 1892, p. 163, type species Paleopneustes hystrix Agassiz, 1880].

TYPE SPECIES. Heterobrissus montesi Manzoni \& Mazzetti, 1878, p. 354.

DiAGNOSIs. Test ovate without anterior sulcus; anterior convex, posterior face short, truncate and undercut. Test domed in profile, with flat base. Apical disc ethmolytic, with four gonopores, a little anterior of centre. Anterior ambulacrum narrow, flush; pore-pairs minute adapically, elsewhere in form of small single oblique slits. Paired ambulacra flush, petaloid adapically, almost parallel-sided and largely open distally; enlarged pore-pairs extending almost to ambitus. No occluded plates at the end of the petals. Peristome lunate, facing forward into frontal groove, with rather projecting labrum. The labral plate extends to the adjacent ambulacral plates 3 . Perioral area sunken. Phyllodes well developed. Sternal, episternal and post episternal plates almost symmetrical, opposite rather than alternate and not indented by the adjacent ambulacral plates. Periproct inframarginal to almost oral, well visible in oral view; adorally it is bounded by the plates 5.a.4 and 5.b.4. Fascioles absent, at least in all the examined specimens with TL $>38 \mathrm{~mm}$. Aboral tuberculation coarse and heterogeneous, made of scrobiculate, perforate and crenulate primary and (rare) secondary tubercles and numerous granules. Posterior ambulacra on oral surface covered in tubercles behind phyllodes. Partially modified from Smith \& Kroh (2011).

SPECIES INCLUDED. - H. montesi Manzoni \& Mazzetti, 1878; Langhian, Italy; Serravallian, Cyprus. 


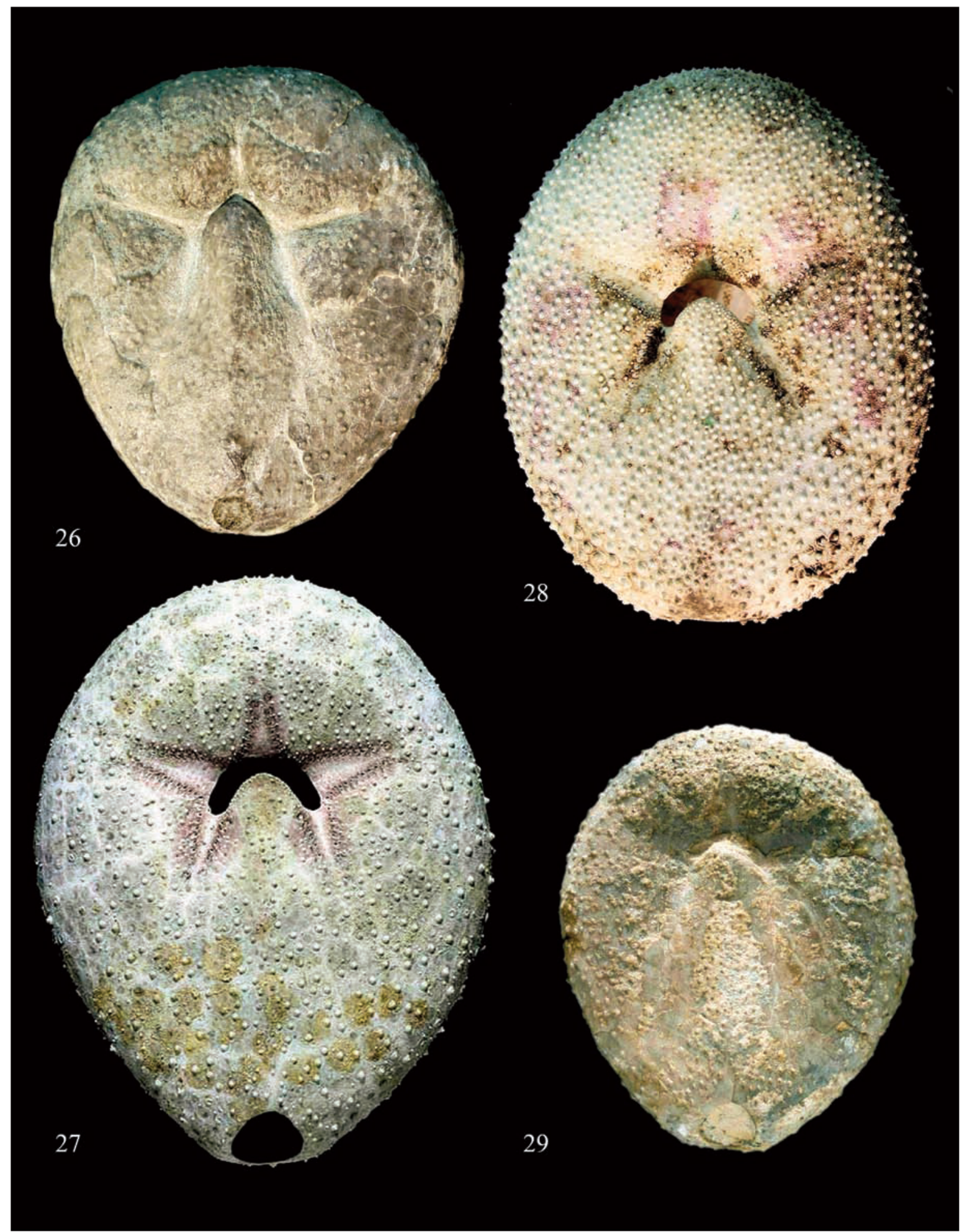

Figures 26-29. Oral face views. Fig. 26: Heterobrissus montesi Manzoni et Mazzetti, 1878 (IGF.101267, TL = 102 $\mathrm{mm}$ ), Langhian, Monte Valestra, near Reggio Emilia. Fig. 27: Heterobrissus hystrix (Agassiz, 1880), MCZ ECH-7813, $\mathrm{TL}=127 \mathrm{~mm}$, Recent, off Florida. Fig. 28: Echinopneustes niasicus (Doderlein, 1901), MAC.IVM210, TL = $124 \mathrm{~mm}$, Recent, Southern China Sea. Fig. 29: Heterobrissus salvae (Cotteau, 1890), CG.01, TL = $62 \mathrm{~mm}$, Late Oligocene of Monteagudo, near Novelda (Spain). 


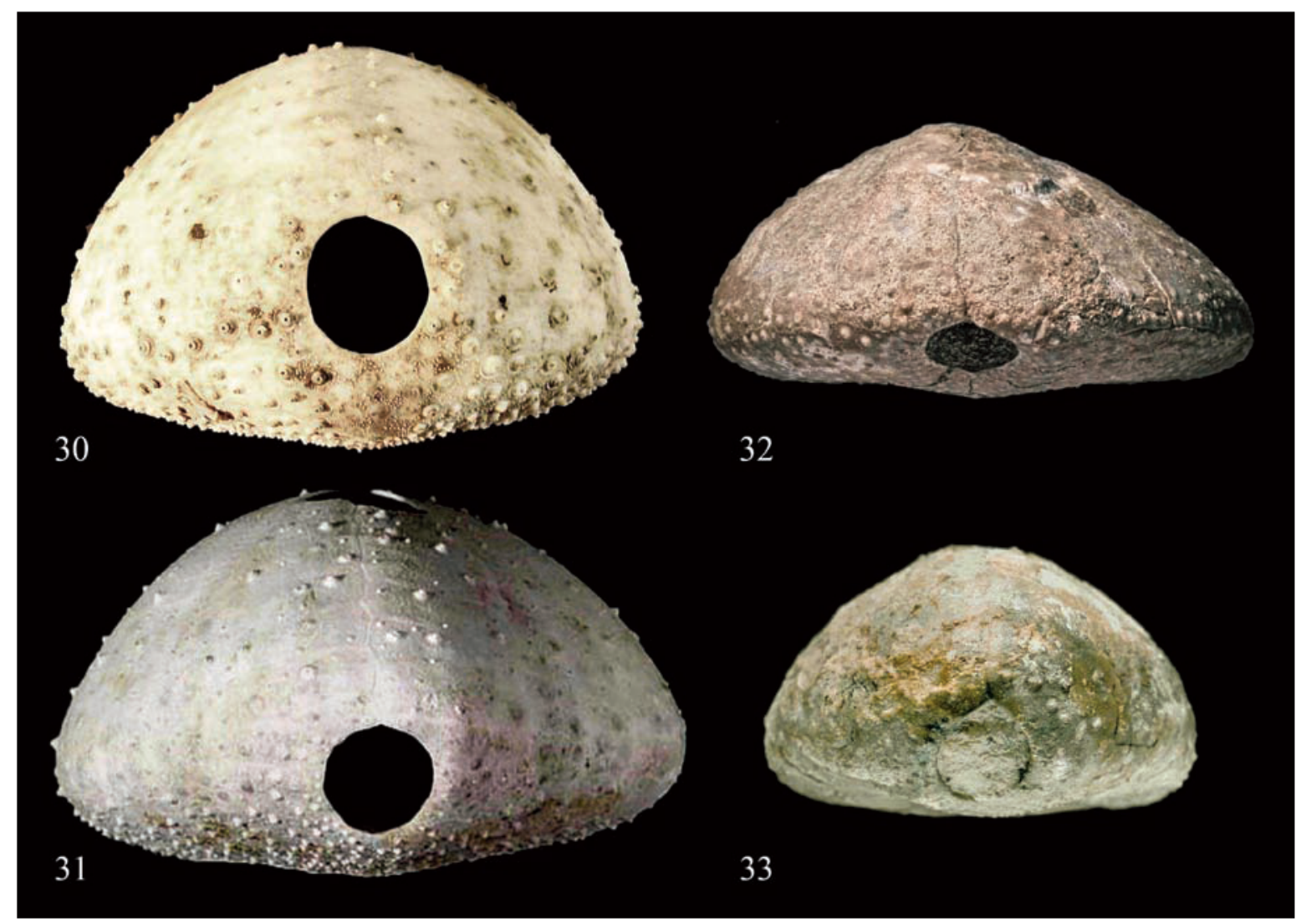

Figures 30-33. Posterior face views. Fig. 30: Echinopneustes niasicus (Doderlein, 1901), MAC.IVM292, TL = $124 \mathrm{~mm}$, Recent, Southern China Sea. Fig. 31: Heterobrissus hystrix (Agassiz, 1880), MCZ ECH-7813, TL = 127 mm, Recent, Florida. Fig. 32. Heterobrissus lubellii n. sp. (MAC.PL1506a, TL=113 mm), Burdigalian, Isili (Sardinia). Fig. 33: Heterobrissus salvae (Cotteau, 1890), CG.01, TL $=84 \mathrm{~mm}$, Oligocene, Monteagudo, near Novelda (Spain).

- H. hystrix (Agassiz, 1880): Recent, Caribbean.

- H. salvae (Cotteau, 1890); ?Eocene and Late Oligocene (Chattian), Spain.

- H. lubellii n. sp., Late Oligocene-Early Aquitanian and Burdigalian, Sardinia (Italy).

Distribution. ?Eocene and Late Oligocene of Spain; Late Aquitanian to Langhian of Italy; Serravallian of Cyprus. Recent, Caribbean.

Heterobrissus montesi Manzoni et Mazzetti, 1878 - Figs. 3-6, 19, 20, 26

1878 - Heterobrissus Montesi Manzoni \& Mazzetti, 354-355, pl. 19, fig. 2.

1879 - Heterobrissus Montesi Manzoni \& Mazzetti Manzoni, 162.

1880 - Heterobrissus Montesi Manzoni \& Mazzetti Manzoni, 189, pl. 3, figs. 24-26.
1881 - Heterobrissus Montesii Manzoni \& Mazzetti Mazzetti, 10.

1901 - Heterobrissus Formai Airaghi, 210, pl. 26,

fig. 6 (fide Stefanini, 1908).

1908 - Heterobrissus Montesii Manzoni \& Mazzetti -

Stefanini, 95-97, pl. 14, figs. 4-5, pl. 15, fig. 1.

1935 - Heterobrissus cypriotes Currie, 32, pl. 3, fig. 1.

2009 - Heterobrissus montesii Manzoni \& Mazzetti -

Smith \& Gale, 123-124, figs. 6-8.

2012 - Heterobrissus montesii Manzoni \& Mazzetti -

Stara et al., 36, pl. 3, fig. 1a-c.

TYPe MATERIAL. The holotype, from Montese (Modena), is missing; it was poorly preserved and the oral face was not visible (Manzoni \& Mazzetti, 1878, pl. 19, fig. 2). After Stefanini (1908), the holotype and the other specimens figured in Manzoni (1880: pl. 3, figs. 24-26) were already missing at that time. 
TYPE LOCALITY. Montese (Province of Modena), Langhian, Pantano Formation.

OTHER EXAMINED MATERIAL. Twelve specimens from Jano, near Sasso Marconi (Province of Bologna) housed at the IGF, including the two figured in Stefanini (1908, pl. 14, figs. 4 and 5) and those reported in his description as "specimens II, III and IV". Five specimens from Monte Valestra, Province of Reggio Emilia (IGF.101266-7, IGF.100345-6), and one from Pescale, Province of Modena (IGF.101268). All of them from the Langhian, Pantano Formation.

DESCRIPTION. Large sized species (TL up to 123 $\mathrm{mm}$ ). Test longitudinally elongate (mean TW $=84 \%$ TL) and more or less constricted posteriorly, with maximum width in front of mid-length (Fig. 3). Test with low domal upper surface and flat oral face, sinking towards the peristome (Fig. 6). Posterior face short and undercut, sometimes almost facing downwards. Test height variable (mean $\mathrm{TH}=$ about $40.5 \% \mathrm{TL}$ ). Ambitus low with rounded margin.

Apical disc - Small, slightly anterior to centre (mean L8 $=55.5 \% \mathrm{TL}$ ), ethmolytic; it has four gonopores, the anteriors are placed closer together than the posteriors.

Ambulacra - Ambulacrum III narrow, flush over the aboral surface (Fig. 3), slightly depressed only as it approaches the peristome (Fig. 26). Adapically there are minute pore pairs; then, starting from the sixth-tenth plate, each plate bears a small slit-like unipore oriented almost vertical to the lower suture, as in H. hystrix (compare Mortensen, 1950, fig. 146b); these pores become lost towards the ambitus. Paired ambulacra petaloid adapically, almost flush, only slightly depressed in their upper half; they extend, slightly diverging, almost to the ambitus, remaining open distally. Pore-pairs become slightly smaller towards the end, where no occluded plates are present. In the anterior paired petals the anterior columns of pore-pairs are smaller than those in the posterior columns as they approach the apex. Porepairs are drop-shaped isopores, with a narrow, flush interporal zone. Anterior paired petals (mean L4 = $45 \% \mathrm{TL}, \mathrm{L} 5=10 \% \mathrm{TL}$ ) slightly flexed to the anterior and diverging from each other at about $130^{\circ}$. Posterior petals longer (mean: L6 $=49.5 \%$ TL, L7 $=11.5 \% \mathrm{TL}$ ), more or less straight and diverging at about $65^{\circ}$. Adorally, the paired ambulacra enlarge and plating becomes crowded as they approach the peristome. Phyllodes well developed, with 6-8 pores in a column in the posterior and the anterior ambulacra and 10-12 in the lateral ambulacra. The pores are single in the phyllodes. There are no enlarged subanal pores.

Interambulacra - Slightly inflated adapically (Fig. 3).

Plastron - Plastron not raised. The labrum strongly indents the peristome (Figs. 6, 26). Labral plate wedge-shaped, with convex surface and always extending to halfway along the third plate in the adjacent ambulacra (Fig. 20). Sternum almost as long as wide, with sternal plates symmetrical and extending to plate 9-10 in the adjacent ambulacral columns (Figs. 4, 19). Episternal plates also paired and about half as long as the sternal plates. Plates 5.a.4 and 5.b.4 weakly offset, "L" shaped and forming the oral border of the periproct. Ambulacral plates do not indent the Interambulacrum 5. All other interambulacra amphiplacous. In the interambulacra 1 and 4 the plates a.5 and b.5 or the a.6. and b. 6 form the ambitus.

Peristome - Sunken, lunate, much wider than long and eccentric anteriorly (mean L9 $=32.5 \% \mathrm{TL}$, range $28.5-36.5 \% \mathrm{TL}$ ).

Periproct - Inframarginal to almost oral and framed by plates 5.a.4, 5.b.4 to 5.a.7, 5.b.7. (Figs. 4,26 ); it is rather small and slightly longitudinally elongate (mean L1 $=10 \% \mathrm{TL}, \mathrm{L} 2=9 \% \mathrm{TL}$ ).

Tuberculation - Primary tubercles scrobiculate, perforate and crenulate (Fig. 5), scattered over the entire aboral face; they become denser approaching the apex and along the mid-line of the posterior interambulacrum. All plates have a covering of sparse miliary granules and occasional smaller tubercles. A few small tubercles also occur within the petals and the frontal ambulacrum. The oral face is fully covered by smaller and denser primary tubercles, including the labral plate and the plastron (Fig. 6). Ambulacral zones have almost identical tuberculation to that in the interambulacral zones, with scattered primary tubercles, except in the phyllodes.

Spines - Primary spines are almost straight aborally, slightly curved in the oral side, some $20-25$ $\mathrm{mm}$ long in adults with $\mathrm{TL}=70-90 \mathrm{~mm}$; they are longitudinally finely striate with a subcircular section and a hollow lumen.

Fascioles - Absent also in well preserved adult specimens. According to Mortensen (1950), the absence of an adproctal widening of the plates in the 
ambulacra I.a and V.b adjoining the episternal plates typically confirms the absence of a subanal fasciole.

REMARKS. The morphological variability includes: test more or less posteriorly constricted and elevated, labrum more or less projecting over the peristome. In the smallest specimens under study (TL $38-50 \mathrm{~mm}$ ) the test outline is sometimes less elongated (Fig. 4), the margin is more inflated, the tuberculation may be less dense and the labrum less projecting over the peristome (Stefanini, 1908).

Heterobrissus salvae (Cotteau, 1890) differs by the plates in the proximal part of the oral ambulacra $\mathrm{I}$ and $\mathrm{V}$, that are longer and, as a consequence, the sternal plates extend only to the ambulacral plates $7-8$, not to the plates 9-10 as in H. montesi. Additionally, the shell is thicker.

Archaeopnuestes abruptus Gregory, 1892, from the Oceanic series of Bissex Hill (Barbados) is represented by a sole specimen of uncertain age (Gregory, 1892). Although not completely preserved, the holotype shows closer affinity to the genus Antillaster Lambert, 1909 based on test profile and petal shape. Indeed, it was assigned to Antillaster by Lambert \& Thiery (1924) and Mortensen (1950). It differs from $H$. montesi also by the anterior paired petals much more diverging (at almost $180^{\circ}$ ) and extending farther towards the ambitus, by "V" shaped aboral plates and less projecting labrum.

Heterobrissus formai Airaghi, 1901, from Pino Torinese (Piedmont, Italy), was distinguished mainly by the scarcity of the primary tubercles on the aboral surface. Based on the available information (Airaghi, 1901), the holotype and only known specimen of this species was collected from the Baldissero Formation (Langhian). The holotype was lost in 1943 (personal communication, D. Ormezzano, MTPL, June 2007) and no other specimens have been subsequently recorded from that area. Stefanini (1908) had the opportunity of examining the type and affirmed that the lack of primary tubercles was due to abrasion; consequently he considered $H$. formai as a junior synonym of $H$. montesi.

Heterobrissus cypriotes Currie, 1935, from the Pakhna Formation (Serravallian) of Alessa near Limossol (Cyprus), was originally based on badly preserved material. Smith \& Gale (2009), with access to better material from the same locality, found no significant differences with the type material from Italy and proposed $H$. cypriotes to be a junior synonym of $H$. montesi. In addition, the oral plating and the structure of the apical disc in the specimens of $H$. montesi under study match with the schemes reported by Smith \& Gale (2009; figs. 7a-c).

Archaeopneustes moorefieldi Hall, 1966, from the Early Pliocene Pismo Formation of California, was based on a sole specimen whose preservation prevents confirmation of the presence of the diagnostic characters of Heterobrissus. The outer pores of the paired petals are not conspicuously larger than the inner ones, as in Heterobrissus (Kier, 1984). Its generic position remains uncertain.

Heterobrissus montesi shows a close similarity with the Recent Heterobrissus hystrix (Agassiz, 1880 ) from the Caribbean. According to Smith \& Stockley (2005) and Smith \& Gale (2009), in $H$. hystrix the peristome is more anteriorly located and more rounded, and the labral plate projects more strongly. Although the difference in the position of the peristome is not confirmed by our dataset (Table 2), H. montesi differs also by its periproct, smaller and almost oral, and by much denser tuberculation aborally; additionally, the primary spines are slender and finely striated longitudinally, not stout and smooth as in H. hystrix (Mortensen, 1950).

Distribution. Langhian of Emilia-Romagna and Piedmont (Northern Italy).

Heterobrissus lubellii $\mathrm{n}$. sp. - Figs. 7-14, 32 http://zoobank.org/2830b226-6f5b-4324-9614da27d4d93c1f

TYPE MATERIAL. The holotype (MDLCA 23788) and seven paratypes (MDLCA 23789, 23790 and 23792; MAC PL1505, PL1506a, PL1508 and PL1861) from the Early Burdigalian of Baraci and Nuraghe Longu, near Isili (Cagliari Province). Other two paratypes (MDLCA 23791 and MAC PL2095) respectively from the Late Burdigalian of Nureci (Oristano Province) and of Genoni (Oristano Province).

TyPe LOCALITY. Baraci and Nuraghe Longu, near Isili (Cagliari Province) 39 $9^{\circ} 44^{\prime} 45.54^{\prime \prime} \mathrm{N}$ 9॰10’07.78”'E.

OTHER EXAMINED MATERIAL. Twenty-five specimens from the Early Miocene of Sardinia: 18 of them from the Early Burdigalian of Isili, 3 from the Late Burdigalian of Nureci, 3 from the Late Burdigalian of Genoni, 1 from the Late Oligocene-Early 
Aquitanian of Calada Bianca, near Funtanazza (Oristano Province).

Diagnosis. A species of Heterobrissus with the paired petals longer and larger than those in the other species belonging to this genus ( $\mathrm{L} 4=52 \%$; L5 = $13.5 \%$; L6 $=55 \%$; L7 $=17 \%$ TL in the holotype) and with the peristome farther from the anterior margin ( $\mathrm{L} 9=38 \% \mathrm{TL}$ in the holotype) (Table 1); the periproct is larger $(\mathrm{L} 1=14 ; \mathrm{L} 2=12 \% \mathrm{TL}$ in the holotype) than that in the type-species of the genus.

DESCRIPTION. Large sized species (TL up to 127 $\mathrm{mm}$ in the studied sample). Test longitudinally elongate (mean TW $=84 \% \mathrm{TL}$ ) and more or less constricted posteriorly, with maximum width in front of mid-length (Fig. 7). Test with low domal upper surface (Figs. 9-14) and flat oral face, sinking towards the peristome (Fig. 8). Posterior face short, undercut and almost facing downwards (Figs. 914). Test height variable (mean $\mathrm{TH}=46 \% \mathrm{TL}$ ). Ambitus low with rounded margin (Fig. 32).

Apical disc - Small, slightly anterior (mean L8 $=57 \% \mathrm{TL}$ ), ethmolytic, with four gonopores, the anterior pores are placed closer together than the posterior pair.

Ambulacra - Ambulacrum III narrow, flush over the aboral surface, slightly depressed only as it approaches the peristome. In the frontal ambulacrum the pores are double only adapically, farther down they are replaced by a narrow slit-like unipore oriented almost vertical to the lower suture (Fig. 12); these pores disappear towards the ambitus. Paired ambulacra petaloid adapically, almost flush, only slightly depressed in their upper half; they extend, slightly diverging, almost to the ambitus, remaining largely open distally (Fig. 7). Pore-pairs become slightly smaller towards the tip of the petal, where no occluded plates are present (Fig. 10). In the anterior paired petals the anterior columns of porepairs are smaller than those in the posterior columns as they approach the apex. Pore-pairs are dropshaped isopores, with a narrow, flush interporal zone. Anterior paired petals long and wide (mean $\mathrm{L} 4=49 \% \mathrm{TL}, \mathrm{L} 5=12.5 \% \mathrm{TL}$ ), diverging from each other at about $130^{\circ}$. Posterior petals more or less longer and wide (mean: L6 $=57 \%$ TL, L7 = $14 \% \mathrm{TL}$ ), more or less straight and diverging at about $65^{\circ}$. Adorally, the paired ambulacra enlarge and the plating becomes crowded as they approach the peristome (Fig. 13). Phyllodes well developed, with 6-8 pores in a column in the ambulacra I, III,
$\mathrm{V}$, and 10-12 in the lateral anterior ambulacra. The pores are single in the phyllodes.

Interambulacra - Only slightly inflated adapically.

Plastron (Fig. 13) - Plastron not raised. The labrum strongly indents the peristome (Fig. 8). Labral plate wedge-shaped, with convex surface and extending to halfway along the third plate in the adjacent ambulacra. Sternum almost as long as wide with sternal plates symmetrical and extending to plates 9-10 in the adjacent ambulacral columns. Episternal plates also paired and about half as long as the sternal plates. Plates 5.a.4 and 5.b.4 weakly offset, "L" shaped and forming the oral border of the periproct. The ambulacral plates do not indent the Interambulacrum 5. All the other interambulacra are amphiplacous. In interambulacra 1 and 4 the plates a. 5 and b.5 or the a.6. and b. 6 form the ambitus.

Peristome - Sunken, lunate, much wider than long and with a strongly projecting labrum. It is eccentric anteriorly but rather far from the test edge (mean L9 $=37 \% \mathrm{TL}$, range $34-38.5 \% \mathrm{TL}$ ).

Periproct - Inframarginal to almost oral (Fig. 32) and framed by plates 5.a.4, 5.b.4 to 5.a.7, 5.b.7. (Fig. 13); it is subcircular to slightly longitudinally elongate (mean $\mathrm{L} 1=13.5 \% \mathrm{TL}, \mathrm{L} 2=11 \% \mathrm{TL}$ ).

Tuberculation - Primary tubercles scrobiculate, perforate and crenulate, scattered over the entire aboral surface. All plates have a covering of sparse miliary granules and occasional smaller tubercles. A few small tubercles also occur within the petals and the frontal ambulacrum. The oral face is fully covered by smaller and denser primary tubercles, including the labral plate and the plastron (Fig. 8). Ambulacral zones have identical tuberculation to that in the interambulacral zones, with scattered primary tubercles, except in the phyllodes.

Fascioles - Absent in well preserved adult specimens. According to Mortensen (1950) the absence of an adproctal widening of the plates in the ambulacra I.a and V.b adjoining the episternal plates, typically confirms the absence of a subanal fasciole.

Eтymology. Dedicated to Giuseppe Lubelli (1938-2013), a collector from Cagliari who provided the authors with the first specimen of Heterobrissus found at Isili (Sardinia).

REMARKs. Heterobrissus salvae (Cotteau, 1890) differs by thicker shell and by the plates in the proximal part of the oral ambulacra I and V, which are longer and, as a consequence, the sternal plates extend only to the ambulacral plates $7-8$, not to the plates 9-10 as in H. lubellii. 
Heterobrissus lubellii $\mathrm{n}$. sp. mainly differs from the Recent $H$. hystrix from the Caribbean area by lower test, periproct more inframarginal (Fig. 32), larger paired petals and much denser aboral tuberculation.

DisTRIBUTION. Late Oligocene-Early Aquitanian and Burdigalian of Sardinia.

Genus Echinopneustes n. gen. - Figs. 23-25, 28, 30, 34-38 - http://zoobank.org/ee07de29-90d84eed-8719-bdbc0653f7b5

TyPe SPECIES. Palaeopneustes niasica Döderlein, 1901 (p. 22).

TYPE MATERIAL. Döderlein (1901) did not designate a type. A syntype (MCZ.2817), dredged from Nias (Indonesia) during the Valdivia expedition, is housed at the Museum of Comparative Zoology, Harvard University (Downey, 1968).

DiAgNosis. Test ovate without anterior sulcus (Fig. 34); anterior convex, posterior face truncate. Test domed in profile, with flat base (Fig. 36). Apical disc ethmolytic, with four gonopores, anterior of centre. Anterior ambulacrum narrow, flush; pore-pairs minute adapically. Paired ambulacra petaloid adapically, most parallel-sided and largely open distally; enlarged pore-pairs extending almost to ambitus. No occluded plates at the end of petals. Peristome lunate with projecting labrum (Figs. 28, 35). Labral plate extending to the adjacent ambulacral plate 2 (Figs. 23-25). Perioral area sunken. Phyllodes well developed (Fig. $35,38)$. Sternal, episternal and post episternal plates almost symmetrical, opposite rather than alternate; ambulacral plates not indenting the oral interambulacrum 5. Periproct large and flush, marginal to supramarginal, located rather high on the posterior test face (Figs. 30, 37), and bounded by the plates 5.a.5 and 5.b.5 in the oral posterior interambulacrum. Fascioles absent, at least in adult specimens. Aboral surface covered in coarse and heterogeneous tuberculation, made of scrobiculate, perforate and crenulate primary tubercles and numerous granules. Oral posterior ambulacra covered in tubercles behind phyllodes. Primary spines sharply pointed; in the type-species they are flattened and densely thorny, and only close to the base they may be round in section.
SPECIES INCLUDED. - E. niasicus (Doderlein, 1901): Recent, Indo-Pacific.

- E. erinaceus (Baker et Rowe, 1990); Recent, Australia.

- E. gigas (Baker et Rowe, 1990); Recent, Australia.

DistRIBUTION. Recent, Indo-Pacific.

DIFFERENTIAL DIAGNOSIS. Echinopneustes n. gen. differs from Heterobrissus mainly in the labral plate being shorter and reaching only plate 2 of the adjoining ambulacra, instead of plate 3 as in Heterobrissus. Additionally, the test outline is not restricted posteriorly (Figs. 28, 35) and the posterior face is larger and steeper (Figs. 30, 36, 37), sometimes almost vertical, so that the periproct cannot be seen in oral view (Figs. 28, 35). The peristome is farther from the anterior margin of the test (Tables 2-3, Figs. 28, 35, 38). The periproct in the type-species is bounded by the interambulacral plates 5.a.5 and 5.b.5, not the 5.a.4 and 5.b.4 as in Heterobrissus (Fig. 38). In Echinopneustes niasicus the primary spines are thorny and flattened distally, whereas they are smooth and round in $H$. hystrix and round and finely striated in $H$. montesi. Ophicephalous pedicellarie are present, whereas they are absent in H. hystrix.

ETYMOLOGy. It derives from the Greek words echinos (sea urchin) and pneuma (breath), referring to the inflated shape of the test.

REMARKS. Echinopneustes n. gen. has no near relation with Palaeopneustes, in which the type species was originally placed by Doderlein (1901). In particular, the oral posterior ambulacra are highly characteristic in being wholly covered with large and small tubercles, not at all naked as it is otherwise usual in Palaeopneustes (Mortensen, 1950).

Echinopneustes erinaceus differs from E. niasicus by the presence of many short spines and the labrum longer than wide. Echinopneustes gigas differs from the other species attributed to Echinopneustes by its larger maximum size (TL up to 165 $\mathrm{mm}$ ), coarser tuberculation, narrower phyllodes area and the presence of large short-bladed globiferous and rostrate pedicellariae (Baker \& Rowe, 1990). A detailed key to distinguish among the Recent species attributed to this genus has been provided by Baker \& Rowe (1990, p. 310). 


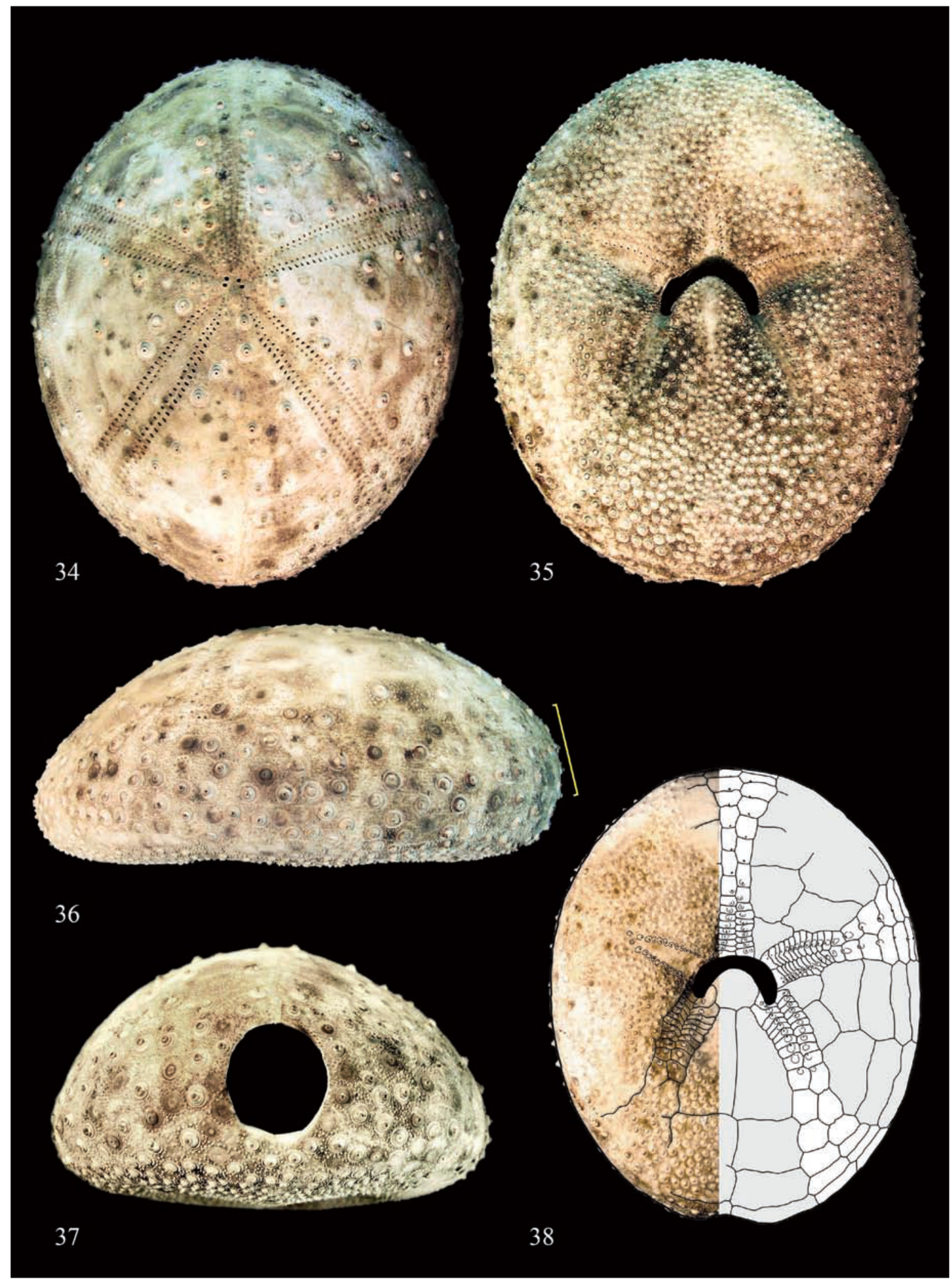

Figures 34-38. Echinopneustes niasicus (Doderlein, 1901), MAC.IVM291, TL = $121 \mathrm{~mm}$, Recent, Southern China Sea: respectively aboral, oral, lateral and posterior views, and oral plating scheme. 


\section{PALAEOECOLOGY}

The presence of an outer shelf setting was prospected in the Pantano Fm at Jano, near Sasso Marconi (Panini et al., 2005), as well as in the Pakhna Fm of Cyprus (Smith \& Gale, 2009). In both the examined areas, a low diversity fauna has been recorded. In particular, in the Serravallian of southern Cyprus the echinoid assemblage is dominated by just two genera of spatangoids, Palaeobrissus A. Agassiz, 1883 and Heterobrissus, both of them today confined to bathyal muddy settings (Smith \& Gale, 2009). In the Langhian of EmiliaRomagna, Heterobrissus is commonly associated with Mazettia pareti (Manzoni, 1879) and Faorina maullui Stara et Borghi, 2012. According to Smith $\&$ Gale (2009), Mazettia is a probable sister taxon to Linopneustes A. Agassiz, 1881, which today lives in 55-710 m water depth, with maximum frequency between 200-500 m (Mortensen, 1950). Faorina Gray, 1851 today inhabits the Indo-Pacific at depths of 41-220 m, associated with Echinopneustes niasicus and Linopneustes spp. (Lane et al., 2000).

Heterobrissus montesi is closely related to $H$. hystrix, today living on muddy bottoms in the Caribbean, at 220-1610 m depth, (Mortensen, 1950; Serafy, 1979). Young et al. (1998) studied the distribution of $H$. hystrix and the thermal tolerances of its embryos and echinopluteus larvae. They found that embryos could tolerate temperatures as high as $25^{\circ} \mathrm{C}$, but larvae died at temperatures above $20^{\circ} \mathrm{C}$. The population of $H$. hystrix inhabiting the slopes of the Bahamian Islands had adult distributions centred at a depth of $550 \mathrm{~m}$, with the upper limit corresponding closely to the thermal tolerances of larvae. At $200 \mathrm{~m}$, in the Caribbean, the water temperature ranges from $15-16^{\circ}$ along the northern Colombian coast to a maximum of $20-21^{\circ}$ in the Cuba-Florida area.(Fuglister, 1954). At $1600 \mathrm{~m}$, the maximum reported bathymetry for this species, the temperature is about $5^{\circ} \mathrm{C}$ (NOOA data, 2009).

Heterobrissus is a large and flat-based echinoid with a heterogeneous aboral spine canopy and without fascioles. The lack of fascioles points to echinoids living epibenthic or inhabiting coarse permeable sediments (Smith \& Stockley, 2005); the first hypothesis is more likely also for the fossil Heterobrissus, since groups of H. hystrix have been observed "patrolling" the bottom surface at the Bahamas Islands (NOAA Photo Library, 2009).

Based on the available evidence and on comparison with living sister taxa and their bathymetric ranges, $H$. montes $i$ was en epibenthic echinoid, inhabiting muddy bathyal settings and harvesting organic detritus from the sediment-water interface.

\section{ACKNOWLEDGEMENTS}

We want to thank Andrew Smith (Department of Paleontology, Natural History Museum of London) for rewieving our first manuscript and Andreas Kroh (Department of Geology \& Paleontology, Natural History Museum of Vienna) for providing bibliographic references and improving suggestions. We are grateful also to Stefano Dominici (Museo di Storia Naturale, Sezione di Geologia e Paleontologia, University of Firenze) and Daniele Ormezzano (Museo Regionale di Storia Naturale, Torino) for allowing access to the collections housed at their departments. We are indebted to five Spanish collectors, Leonardo Hernandez, Clifford Saint Clair and Jose Carlos Saldaña (Alicante), Carlos Garcia (Madrid) and Manuel Adell Alegre (Vinaròs), for providing us with information and fossil material from the Oligocene of Novelda, near Alicante (Spain). Thanks are due too to the Museum of Comparative Zoology of Harvard University, Cambridge, USA allowed us to reproduce the illustration of a Recent specimen of Heterobrissus hystrix (MCZ ECH-7813). G. Zachos (Department of Geology \& Geological Engineering, University of Mississippi, USA), Francisco Carrasco (Museo Geologico del Seminario, Barcelona, Spain), Diego Garcia Ramos (Asociación Cultural Paleontológica Murciana, Murcia, Spain) and Roberto Rizzo (Parco Geominerario Storico Ambientale della Sardegna, Italy), are warmly thanked for providing information about the geology of the finding localities and for bibliographic references. Thanks also to Massimo Scanu (Miniere di Sardegna, Sanluri, Cagliari) and Claudio Ronzitti (Quartu S.Elena, Cagliari, Sardinia) donated to the MAC some specimens of Heterobrissus from Funtanazza and Isili. Lastly, we want to thank Luca Bertolaso and Giuseppe Ascari (Società di Reggiana di Scienze Naturali, Reggio Emilia) prepared fossil specimens from the Northern Apennines for the study. 


\section{REFERENCES}

Agassiz A., 1880. Preliminary report on the echini. Reports on the results of dredging, under the supervision of Alexander Agassiz, in the Caribbean Sea in 18781879 , and along the Atlantic Coast of the United States during the summer of 1880 , by the U.S. Coast Survey Steamer "Blake". IX. Bulletin of the Museum of Comparative Zoology of Harvard, 8: 69-84.

Agassiz A., 1881. Report on the scientific results of the voyage of the H.M.S. "Challenger" during the years 1873-1876, Zoology, Vol. III, Part IX, Report on the Echinoidea. Longmans \& Company ed., London, 321 pp.

Agassiz A., 1883. Report on the results of dredging under the supervision of Alexander Agassiz, in the Gulf of Mexico (1877-1878), in the Caribbean Sea (187879), and along the Atlantic coast of the United States (1880), by the U.S. Coast Survey Steamer "Blake", Lieut.-Com. C. D. Sigsbee, U.S.N., and Commander J. R. Bartlett, U.S.N., commanding. XXIV, Part 1. Report on the Echini. Memoirs of the Museum of Comparative Zoology at Harvard College 10/1, Cambridge, MA: i-v+1-94.

Agassiz L., 1840. Catalogus systematicus Ectyporum Echinodermatum fossilium Musei Neocomiensis, secundum ordinem zoologicum dispositus; adjectis synonymis recentioribus, nec non stratis et locis in quibus reperiuntur. Sequuntur characteres diagnostici generum novorum vel minus cognitorum. Petitpierre, Neuchâtel, 20 pp.

Airaghi C., 1901. Echinidi terziari del Piemonte e della Liguria. Palaeontographia Italica, 7: 22-126.

Alcock A., 1902. A Naturalist in Indian Seas; Or, Four Years with the Royal Indian Marine Survey Ship Investigator. Journal of Asiatic Society of Bengal, 1: 177-184.

Amorosi A., 1996. Miocene shallow-water deposits of the northern Apennines: a stratigraphic marker across a dominantly turbidite foreland-basin succession. Geologie en Mijnbouw, 75: 295-307.

Amorosi A., Colalongo M.L. \& Vaiani S.C., 1993. Le unità epiliguri nel settore emiliano dell'Appennino settentrionale. Biostratigrafia, stratigrafia sequenziale e implicazioni litostratigrafiche. Paleopelagos, 3: 209-240.

Amorosi A., Colalongo M.L. \& Vaiani S.C., 1996. Revisione litostratigrafia dell'unità Bismantova (Miocene epiligure, Appennino settentrionale). Bollettino della Società Geologica Italiana, 115: 355-367.

Annino E., Barca S. \& Costamagna L.G., 2000. Lineamenti stratigrafico-strutturali dell'Arburese (Sardegna sudoccidentale). Rendiconti del seminario della Facoltà di Scienze, Università di Cagliari, 70 (Suppl.): 403-426.
Assorgia A., Barca S. \& Spano C., 1992. Upper Oligocene - Lower Miocene sequences of the Arbus - Funtanazza Coast (South - Western Sardinia, Italy). In: Carmignani L. \& Sassi F.P. (Eds.), Volume dedicato a Tommaso Cocozza. IGCP N. 276, Newsletter (1992), 5: 21-31.

Assorgia A., Barca S., Flore G., Lonis R., Luxoro S., Pinna M., Porcu A., Secchi F. \& Spano C., 1995. Carta geologica del settore vulcanico e sedimentario cenozoico compreso tra Fordongianus e Sini (Sardegna Centrale). Progemisa S.P.A. ed. 1995.

Azema J., Devries A. \& Magne J., 1969. Observations sur les formations oligocènes supérieures à échinodermes des Sierras du Horna et du Monteagudo (Prov. d'Alicante, Espagne). Bulletin de la Société Géologique de France, 11: 45-48.

Baker A.N. \& Rowe F.W.E., 1990. Atelostomatid sea urchins from Australian and New Zealand waters (Echinoidea: Cassiduloida, Holasteroida, Spatangoida, Neolampadoida). Invertebrate Taxonomy, 4: 281-316.

Bettelli G., Bonazzi U., Fazzini P. \& Panini F., 1989. Schema introduttivo alla geologia delle Epiliguridi dell'Appennino modenese e delle zone limitrofe. Memorie della Società Geologica Italiana, 39 (1987): 487-498.

Borghi E., 2012. Il genere Spatangus (Echinoidea) nel Langhiano dell'Appennino reggiano. Notiziario della Società Reggiana di Scienze Naturali (2010): 43-61.

Borghi E., 2013. Il genere Mazettia (Maretiidae) un caratteristico echinoide del Miocene dell'Emilia-Romagna. Notiziario della Società Reggiana di Scienze Naturali: 9-20.

Chesher R.H., 1968. The systematics of sympatric species in West Indian spatangoids: a revision of the genera Brissopsis, Plethotaenia, Paleopneustes, and Saviniaster. Studies in Tropical Oceanography, 7: 1168.

Cotteau G., 1871. Echinides nouveaux ou peau connus. Première séries. Extraits de la Revue et Magazine de Zoologie, 84-90: 153-167.

Cotteau G., 1877. Description des Echinides. In: Locard A. (Ed.), Description des Faune des terrains Tertiaires moyen de la Corse. Annales de la Société d'Agriculture, Historie Naturelle et Arts utiles de Lyon, 1877: 227-335.

Cotteau G., 1890. Echinides éocènes de la province d'Alicante. Mémoires de la Société géologique de France, séries 3, tome 5, mémoires 2: 1-107.

Currie E.D., 1935. Report on Miocene echinoids from Cyprus collected by Dr. F.R.C. Reed. Annals and Magazine of Natural History, Series 10 (15): 31-37.

Dames W., 1877. Die Echiniden der Vicentinischen und Veronesischen Tertiaerablagerungen. Paleontographica, Cassel, 99 pp. 
Döderlein L., 1901. Diagnosen einiger von der Valdivia - Expedition gesammelten Seeigel-Arten aus dem Indischen Ocean. Zoologischen Anzeiger, 24: 1923.

Downey M.E., 1968. Catalog of Recent Echinoid Type Specimens in the U.S. National Museum Smithsonian Institution and the Museum of Comparative Zoology Harvard University. Bulletin of the United States National Museum, 264: 1-99.

Fischer A.G., 1966. Spatangoids. In: Moore R.C. (Ed.), Treatise on Invertebrate Paleontology, Part U. Echinodermata. 3(2). Geological Society of America and University of Kansas Press, Boulder and Lawrence. U543-U628.

Fuglister F.C., 1954. Average temperature and salinity at a depth of 200 meters in the North Atlantic. Woods Hole Oceanographic Institution, Tellus, 6: 46-58.

Gregory J.W., 1892. Archaeopneustes abruptus, a new genus and species of echinoid from the Oceanic Series in Barbados. Quarterly Journal of the Geological Society, 48: 163-169.

Hall C.A., 1966. Archaeopneustes moorefteldi, a New Pliocene Spatangoid Echinoid from the San Luis Obispo Area, California. Journal of Paleontology, 40: 1123-1126.

Kier P.M., 1984. Fossil Spatangoid Echinoids of Cuba. Smithsonian Contributions Paleobiology, 55: 1-336.

Kroh A. \& Smith A.B., 2010. The phylogeny and classification of post-Palaeozoic echinoids. Journal of Systematic Palaeontology, 8: 147-212.

Kroh A. \& Mooi R., 2019. World Echinoidea Database. Archaeopneustes hystrix (A. Agassiz, 1880). Accessed through: World Register of Marine Species at: $\mathrm{http}: / /$ www.marinespecies.org/aphia.php?p=taxdetails\&id $=422506$ on 2019-03-04

Kroh A. \& Mooi R., 2019. World Echinoidea Database. Heterobrissus Manzoni \& Mazzetti, 1878. Accessed through: World Register of Marine Species at: $\mathrm{http}: / / w w w . m a r i n e s p e c i e s . o r g / a p h i a . p h p ? p=t a x d e-$ tails\&id $=512832$ on 2019-02-03.

Lambert J.M. \& Thiery P., 1909-1925. Essai de nomenclature raisonnée des Echinides. Librairie L. Ferriere, Chaumont, $607 \mathrm{pp}$.

Lane D.J.W., Marsh L.M., Vanden Spiegel D. \& Rowe F.W.E., 2000. Echinoderm fauna of the South China Sea: an inventory and analysis of distribution patterns. The Raffles Bulletin of Zoology, Suppl. 8: 459 493.

Laube G.C., 1869. Die Echinoiden der österreichischungarischen oberen Tertiärablagerungen. Verhandlungen der kaiserlich-königlichen Geologischen Reichsanstalt, 3: 182-184.

López J. \& Sillero C., 2006. Equinidos Fósiles de la Provincia de Alicante. Memorias del Museo Paleontológico de Elche, 2: 1-154.
Lovén S., 1874. Etudes sur les Echinoidees. Kongelige Svenska Vetenskaps-Akademiens Handlingar, 11: 191.

Mancosu A., Nebelsick J.H., 2016. Echinoid assemblages from the Early Miocene of Funtanazza (Sardinia): a tool for reconstructing depositional environments along a shelf gradient. Palaeogeography, Palaeoclimatology, Palaeoecology, 454: 139-160.

Manzoni A., 1879. Gli echinodemi fossili dello Schlier delle colline di Bologna. Denkschriften der kaiserlichen Akademie der Wissenschaften, mathematischnaturwissenschaftliche Classe, 39: 149-164.

Manzoni A., 1880. Echinodermi fossili della molassa serpentinosa e supplemento agli echinodermi dello Schlier della colline di Bologna. Denkschriften der Kaiserlichen Akademie der Wissenschaften mathematisch-naturwissenschaftliche Classe, Wien, 42: 185-190.

Manzoni A. \& Mazzetti G., 1878. Echinodermi nuovi della Molassa Miocenica di Montese nella Provincia di Modena. Atti della Società Toscana di Scienze Naturali, 3: 350-356.

Mapa Geologico de España, escala 1:50000. Hoja 871, Elda. Istituto Geologico y Minero de Espana. Segunda serie, primiera edicion, 1978.

Mapa Geologico de España, escala 1:50000, 1994. Hoja 848, Benidorm. Istituto Geologico y Minero de Espana. Segunda serie, primiera edicion.

Markov A.V. \& Solovjev A.N., 2001. Echinoids of the family Paleopneustidae (Echinoidea, Spatangoida), morphology, taxonomy, phylogeny. Geos Trudy Paleontologicheskogo Instituta, Rossikaia Akademia Nauk, 280: 1-108.

Mazzetti G., 1881. Echinodermi fossili di Montese. Annali della Società dei Naturalisti di Modena, 15: 118.

McNamara K.J. \& Melikov O.H., 2002. The asterostomatid echinoid Antillaster from the Paradash Group (Middle Eocene) of the Nakhichevan Region of Azerbaijan. Records of the Western Australian Museum, 21: 157-165.

Mortensen T., 1950. A monograph of the Echinoidea V. Spatangoida 1. A. Reitzel, Copenhagen, 432 pp.

NOAA Source Photo Library, 2009. Bioluminescence 2009 Expedition, NOAA/OER - expl. 2133. National Oceanic and Atmospheric Administration. Accessed (Oct.31.2019) through: commons.m.wikimedia.org/ wiki/File:Heterobrissus_hystrix.jpg.

Panini F., Bettelli G. \& Pizziolo M., 2005. Note Illustrative della Carta Geologica d'Italia, scala 1:50.000. Foglio 237, Sasso Marconi. Servizio Geologico d'Italia, Roma, $176 \mathrm{pp}$.

Pomel A., 1883. Classification méthodique et genera des échinides vivante et fossiles. Thèses présentées a la Faculté des Sciences de Paris pour obtenir le Grade 
de Docteur dès Sciences Naturelles 503. Adolphe Jourdan, Alger, $131 \mathrm{pp}$.

Rosenbaum G., Lister G.S. \& Duboz C., 2002. Reconstruction of the tectonic evolution of the Western Mediterranean since the Oligocene. In: Rosenbaum G. \& Lister G.S. (Eds.), Reconstruction of the evolution of the Alpine-Himalayan Orogen. Journal of the Virtual Explorer, World Wide Web electronic publication (http://virtualexplorer.com.au), 8: 107-130.

Serafy K.D., 1979. Memoirs of the Hourglass Cruises, Echinoids (Echinodermata: Echinoidea). Florida Department of Natural Resources Marine Research Laboratory, $119 \mathrm{pp}$.

Smith A.B. \& Stockley B., 2005. Fasciole pathways in spatangoid echinoids: a new source of phylogenetically informative characters. Zoological Journal of the Linnean Society, 144: 15-35.

Smith A.B. \& Gale A., 2009. The pre-Messinian deepsea Neogene echinoid fauna of the Mediterranean: Surface productivity controls and biogeographical relationships. Palaeogeography, Palaeoclimatology, Palaeoecology, 281: 115-125.

Smith A.B. \& Kroh A. (Eds.), 2011. The Echinoid Directory. World Wide Web electronic publication. http:// www.nhm.ac.uk/our-science/data/echinoid-directory/taxa/taxon.jsp?id=420 [accessed October. 31 . 2019].

Sowerbutts A. \& Underhill J.R., 1998. Sedimentary response to intra-arc extension: controls on OligoMiocene deposition, Sarcidano sub-basin, Sardinia. Journal of the Geology Society, 155: 491-508.

Stara P. \& Borghi E., 2012. First fossil record of the genus Faorina (Echinoidea: Pericosmidae). Bollet- tino della Società Paleontologica Italiana, 51: 8598.

Stara P., Sanciu L. \& Rizzo R., 2012. Segnalazione di una associazione ad echinidi con spatangoidi prevalenti in Sardegna. Notiziario della Società Reggiana di Scienze Naturali (2010): 27-42.

Stara P. \& Rizzo, 2013. Diffusion of Amphiope Agassiz, 1840 (Astriclypeidae, Clypeasteroida) from the Western proto-Mediterranean Sea, towards the Eastern Neotethys, XIII Giornate di Paleontologia, Perugia, May 23-25, 2013, Riassunti: 119-120, poster.

Stara P., Borghi E., \& Kroh A., 2016. Revision of the genus Mariania (Echinoidea) with the description of two new species from the Miocene of Italy. Bulletin of Geosciences, 91: 65-88.

Stefanini G., 1908. Echinidi del Miocene medio dell'Emilia (Parte prima). Palaeontographia Italica, 14: 65120.

Stockley B., Smith A.B., Littlewood D.T.J., Lessios H.A. \& MacKenziedodds J.A, 2005. Phylogenetic relationships of spatangoid sea urchins (Echinoidea): taxon sampling density and congruence between morphological and molecular estimates. Zoologica Scripta, 34: 447-468.

Young C.M., Ekaratne S.U.K. \& Cameron J., 1998. Thermal tolerances of embryos and planktotrophic larvae of Archaeopneustes hystrix (A. Agassiz) (Spatangoidea) and Stylocidaris lineata (Mortensen) (Cidaroidea), bathyal echinoids from the Bahamian Slope. Journal of Experimental Marine Biology and Ecology, 223: 65-76.

Zittel K.A. von, 1879. Handbuch der Paläontologie, 1: 1-765. 
. 